\title{
Towards a methodology to formulate sustainable diets for livestock: accounting for environmental impact in diet formulation
}

\author{
S. G. Mackenzie ${ }^{1 *}$, I. Leinonen ${ }^{1}$, N. Ferguson ${ }^{2}$ and I. Kyriazakis ${ }^{1}$ \\ ${ }^{1}$ School of Agriculture, Food and Rural Development, Newcastle University, Newcastle upon Tyne, NE1 7RU, UK \\ ${ }^{2}$ Trouw Nutrition Canada, 150 Research Ln, Guelph, ON N1G 4T2, Canada \\ (Submitted 12 October 2015 - Final revision received 7 February 2016 - Accepted 10 February 2016 - First published online 18 March 2016)
}

\section{Abstract}

The objective of this study was to develop a novel methodology that enables pig diets to be formulated explicitly for environmental impact objectives using a Life Cycle Assessment (LCA) approach. To achieve this, the following methodological issues had to be addressed: (1) account for environmental impacts caused by both ingredient choice and nutrient excretion, (2) formulate diets for multiple environmental impact objectives and (3) allow flexibility to identify the optimal nutritional composition for each environmental impact objective. An LCA model based on Canadian pig farms was integrated into a diet formulation tool to compare the use of different ingredients in Eastern and Western Canada. By allowing the feed energy content to vary, it was possible to identify the optimum energy density for different environmental impact objectives, while accounting for the expected effect of energy density on feed intake. A least-cost diet was compared with diets formulated to minimise the following objectives: non-renewable resource use, acidification potential, eutrophication potential, global warming potential and a combined environmental impact score (using these four categories). The resulting environmental impacts were compared using parallel Monte Carlo simulations to account for shared uncertainty. When optimising diets to minimise a single environmental impact category, reductions in the said category were observed in all cases. However, this was at the expense of increasing the impact in other categories and higher dietary costs. The methodology can identify nutritional strategies to minimise environmental impacts, such as increasing the nutritional density of the diets, compared with the least-cost formulation.

Key words: Sustainable livestock diets: Environmental impacts: Nutritional strategies: Diet formulation: Life Cycle Assessment

In commercial pig farming systems, it is typical for nutritionists to formulate diets for economic objectives ${ }^{(1)}$ such as revenue/ feed cost or feed cost $/ \mathrm{kg}$ live weight (LW) gain ${ }^{(2)}$. This is most commonly done through the use of linear programming. More recently, however, sustainability objectives rather than economic ones have increasingly come into consideration in diet formulation. There has been an increased interest in the quantification and mitigation of the environmental impacts of the livestock industry ${ }^{(3)}$. Assessing farming operations in more ways than just their economic 'bottom line' may become more important as part of efforts to improve the sustainability of livestock systems.

For pig farming systems, feed production and manure management are the main sources of environmental impacts, for example ${ }^{(4-6)}$. Life Cycle Assessment (LCA) is a generally accepted method to evaluate holistically the environmental impact during the entire life cycle of a product or system ${ }^{(7)}$, and there are many metrics through which environmental impacts can be quantified. Carbon footprint or global warming potential (GWP) is the metric that has received the most attention in the recent past ${ }^{(8)}$. Analyses of livestock systems using LCA have shown that monogastric animal production systems cause less GWP than meat production from ruminants, whether measured per $\mathrm{kg}$ of product or protein produced ${ }^{(9-11)}$. Pork production is, however, associated with relatively high levels of other environmental impact categories including non-renewable resource use (NRRU), acidification potential (AP) and eutrophication potential $(\mathrm{EP})^{(9,10)}$. The production of feed is responsible for the majority of GWP (up to $65 \%)^{(4,6,12)}$ and NRRU (up to $\left.90 \%\right)^{(5)}$ resulting from pig farming systems. The majority of AP and EP caused by pig production is due to emissions during manure storage and application, as a direct result of the excretion of $\mathrm{N}$ and $\mathrm{P}$ by the animal ${ }^{(6,13,14)}$. As such, the ingredient and nutritional composition of pig diets are extremely important considerations when quantifying the environmental impacts of pig production systems.

Abbreviations: AP, acidification potential; DDGS, dried distillers grains with solubles; EP, eutrophication potential; GWP, global warming potential. LCA, Life Cycle Assessment; LCI, life cycle inventory; least-cost EFF, least cost/kg live weight gain while maximising feed efficiency within commercial constraints; least EI, least combined environmental impact score; LW, live weight; NE, net energy; NRRU, non-renewable resource use.

* Corresponding author: S. G. Mackenzie, email s.g.mackenzie@ncl.ac.uk 
The objective of this study was to develop a novel methodology that enables pig diets to be formulated explicitly for environmental impact objectives using an LCA approach, while not penalising animal growth. The methodology was associated with the following challenges: (1) how to account for environmental impacts caused by both nutrient excretion and ingredient choice, (2) how to formulate diets for multiple environmental impact objectives and (3) how to identify the optimal nutritional composition of diets for different objectives. An LCA model for Canadian pig farming systems was integrated into a diet formulation tool. The LCA model was then used to quantify the potential reductions that can be made to the environmental impact of Canadian pig farming systems through explicitly optimising diets for this purpose in a diet formulation tool.

\section{Methods}

\section{The system under consideration}

Modern pig farming systems can be considered to have three distinct production phases: (1) gestation and farrowing where piglets are produced by breeding sows, (2) the nursery or weaning phase when pigs are separated from their mothers and (3) the grower/finisher $(\mathrm{G} / \mathrm{F})$ phase where pigs are fattened from about $30 \mathrm{~kg}$ to slaughter weight ${ }^{(15)}$. Fig. 1 shows the major components of this system when considered in an LCA model: from the production of feed ingredients to animals shipped from the farm gate for slaughter. There were three main compartments of material flow considered in the LCA model: (1) the production of feed ingredients, (2) the consumption of feed, energy and other materials for on-farm pig production and (3) the storage and land application of manure. Benchmark data from 2012 on Canadian pig farms showed that $78 \%$ of feed consumed per pig produced at least $75 \%$ of the environmental impacts that occurred during the $\mathrm{G} / \mathrm{F}$ phase ${ }^{(5)}$. Attention therefore was given to formulating diets only for the $G / F$ phase

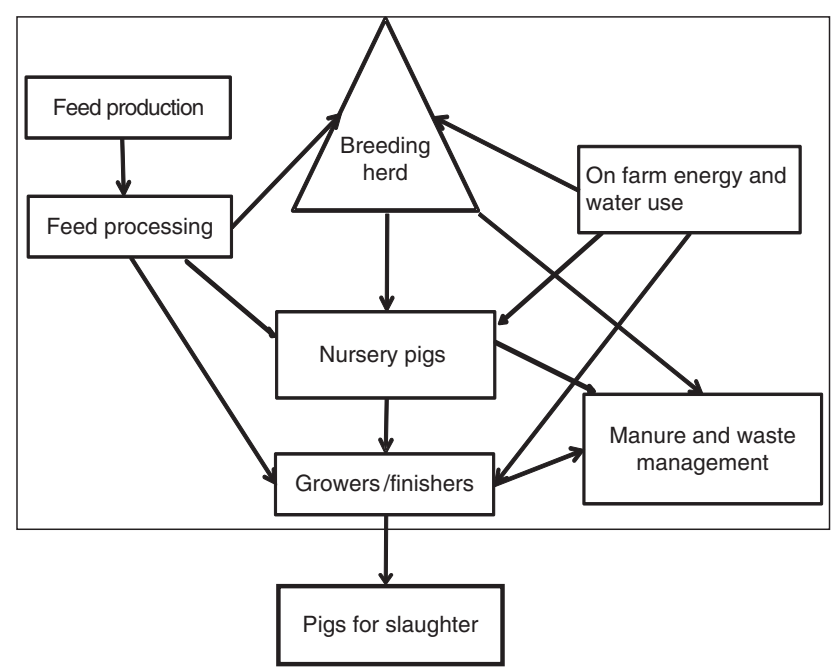

Fig. 1. The structure and main components of the pig production systems as considered by the Life Cycle Assessment model. Feed production in the model included the manufacture of fertilisers and pesticides, etc. as inputs to growing crops. of production. Diets were formulated in two scenarios for pig production systems in Eastern and Western Canada because the main ingredients used in their typical diets are not the same. Pig diets in Eastern Canada are typically based on maize similar to US pig diets ${ }^{(16)}$, whereas pig diets in Western Canada use wheat and barley as the main cereal component $/ \mathrm{s}^{(17)}$.

\section{The life cycle assessment model}

The environmental impacts resulting from all diets formulated in this study were calculated using an LCA model of pig systems in Eastern and Western Canada ${ }^{(5)}$. Some aspects of this model were also included as part of the diet formulation process (see Diet formulation rules). The details regarding the main components of the LCA model of Canadian pig farming systems are provided below. The system boundaries of the LCA were cradle to farm gate and the functional unit was $1 \mathrm{~kg}$ expected carcass weight $(\mathrm{ECW})^{(5)}$. The breeding and nursery production stages were treated as independent to the G/F phase in this study and remained constant for all comparisons made.

\section{Feed production}

The average environmental impacts per $\mathrm{kg}$ of ingredient for all ingredients used in the $\mathrm{G} / \mathrm{F}$ diets can be found in Table 1 . Important causes of environmental impact in the feed supply chain for pigs include the following: fossil fuel inputs for fertiliser production, emissions resulting from the spreading of fertilisers, fossil fuel use for field operations, energy inputs to processing (drying, grinding, etc.) and transport ${ }^{(18)}$. When modelling a complex supply chain, as is the case for animal feed, the inputs to the process (wheat, water, energy, etc.) are shared between the different co-products resulting from these processes, and the environmental impacts associated with them must be allocated. Economic allocation was used as the methodology for co-product allocation throughout the feed supply chain, as advised in the FAO Livestock Environmental Assessment and Performance Partnership recommendations ${ }^{(19)}$. The price ratios found in the online Supplementary Material S1 were used for the purposes of economic allocation. Life cycle inventory (LCI) data for the production of major crops were adapted from a previous LCA on Canadian crop production ${ }^{(20)}$. LCI data for amino acids lysine, methionine, threonine and tryptophan were obtained from an LCA study on the impact of amino acids in pig diets ${ }^{(21)}$. LCI data for the production of minerals dicalcium phosphate, salt and limestone came from the Ecoinvent databases ${ }^{(22)}$. LCI data for maize dried distillers grains with solubles (DDGS) from Canadian sources were not available, and therefore were adapted from data representative of ethanol production in the USA ${ }^{(22)}$, assuming the use of Canadian maize and typical electricity mix. The LCI for bakery meal was based on data provided by a large retailer of bakery meal (Sugarich Ltd, unpublished results) and adapted for a Canadian scenario ${ }^{(23)}$. Surplus material from bread production is a large proportion of the material used for bakery meal sold for use in monogastric diets (Sugarich Ltd, unpublished results) and was used as a representative input to bakery meal in this study. The LCI for the production of $1 \mathrm{~kg}$ bread was adapted from the LCA food database ${ }^{(24)}$ with the input of Canadian wheat and energy 
Table 1. Average environmental impacts per $\mathrm{kg}$ for all feed ingredients included in the grower/finisher diets tested

\begin{tabular}{|c|c|c|c|c|c|}
\hline \multirow{2}{*}{$\begin{array}{l}\text { Impact category... } \\
\text { Unit... }\end{array}$} & \multirow{2}{*}{$\frac{\mathrm{NRRU}}{\mathrm{kg} \mathrm{Sb} \mathrm{eq}}$} & \multirow{2}{*}{$\frac{\mathrm{AP}}{\mathrm{kg} \mathrm{SO} \mathrm{O}_{2} \mathrm{eq}}$} & \multirow{2}{*}{$\frac{\mathrm{EP}}{\mathrm{kg} \mathrm{PO}_{4} \mathrm{eq}}$} & \multirow{2}{*}{$\frac{\mathrm{GWP}}{\mathrm{kg} \mathrm{CO}_{2} \mathrm{eq}}$} & \multirow{2}{*}{$\frac{\text { Combined environmental impact score }}{\text { No units }}$} \\
\hline & & & & & \\
\hline Barley & $2 \cdot 18 \mathrm{E}-03$ & $5 \cdot 36 \mathrm{E}-03$ & $2 \cdot 69 \mathrm{E}-03$ & 0.38 & $8 \cdot 20 \mathrm{E}-14$ \\
\hline Rapeseed meal & $1.39 \mathrm{E}-03$ & 7.97E-03 & $1.59 \mathrm{E}-03$ & 0.30 & $8.53 \mathrm{E}-14$ \\
\hline Rapeseed oil & $3.84 \mathrm{E}-03$ & $2 \cdot 20 \mathrm{E}-02$ & 4.40E-03 & 0.84 & $2 \cdot 36 \mathrm{E}-13$ \\
\hline Maize & $1.71 \mathrm{E}-03$ & $5 \cdot 13 \mathrm{E}-03$ & $1.11 \mathrm{E}-03$ & 0.39 & $6 \cdot 55 \mathrm{E}-14$ \\
\hline Soyameal & $5 \cdot 70 \mathrm{E}-04$ & 4.11E-03 & $8 \cdot 71 \mathrm{E}-04$ & 0.15 & 4.33E-14 \\
\hline Wheat & $1.84 \mathrm{E}-03$ & $1.01 \mathrm{E}-02$ & $2 \cdot 04 \mathrm{E}-03$ & 0.43 & $1 \cdot 10 \mathrm{E}-13$ \\
\hline Meat (pork) meal & $1.05 \mathrm{E}-03$ & $2 \cdot 46 \mathrm{E}-04$ & $6 \cdot 16 \mathrm{E}-05$ & $0 \cdot 13$ & $1 \cdot 21 \mathrm{E}-14$ \\
\hline Maize DDGS & $6 \cdot 51 \mathrm{E}-03$ & $1 \cdot 13 \mathrm{E}-03$ & $2 \cdot 66 \mathrm{E}-04$ & 0.78 & $7 \cdot 05 \mathrm{E}-14$ \\
\hline Wheat bran & $1.02 \mathrm{E}-03$ & $5 \cdot 56 \mathrm{E}-03$ & $1 \cdot 12 \mathrm{E}-03$ & 0.24 & $6.07 \mathrm{E}-14$ \\
\hline Wheat shorts & $5 \cdot 12 \mathrm{E}-04$ & $2 \cdot 78 \mathrm{E}-03$ & $5.59 \mathrm{E}-04$ & 0.12 & 3.03E-14 \\
\hline Field peas & $1.32 \mathrm{E}-03$ & $2 \cdot 31 \mathrm{E}-03$ & $2 \cdot 72 \mathrm{E}-03$ & 0.58 & $5 \cdot 98 \mathrm{E}-14$ \\
\hline Bakery meal & $5 \cdot 17 \mathrm{E}-04$ & $1.41 \mathrm{E}-03$ & $2 \cdot 60 \mathrm{E}-04$ & 0.08 & $1.73 \mathrm{E}-14$ \\
\hline Animal-vegetable fat blend & $2.57 \mathrm{E}-03$ & $1.01 \mathrm{E}-02$ & $2.06 \mathrm{E}-03$ & 0.49 & $1 \cdot 16 \mathrm{E}-13$ \\
\hline Soya oil & $1.51 \mathrm{E}-03$ & $1.09 \mathrm{E}-02$ & $2 \cdot 30 \mathrm{E}-03$ & 0.40 & $1 \cdot 15 \mathrm{E}-13$ \\
\hline HCl-Lys & $3.51 \mathrm{E}-02$ & $2 \cdot 12 \mathrm{E}-02$ & $9.97 \mathrm{E}-03$ & 4.81 & $5 \cdot 68 \mathrm{E}-13$ \\
\hline L-Thr & $3.51 \mathrm{E}-02$ & $2 \cdot 12 \mathrm{E}-02$ & 9.97E-03 & $4 \cdot 81$ & $5 \cdot 68 \mathrm{E}-13$ \\
\hline DL-Met & $3.64 \mathrm{E}-02$ & $7.54 \mathrm{E}-03$ & $1.70 \mathrm{E}-03$ & 2.95 & $3.71 \mathrm{E}-13$ \\
\hline L-Try & $7.01 \mathrm{E}-02$ & $4 \cdot 24 \mathrm{E}-02$ & $1.99 \mathrm{E}-02$ & 9.62 & $1 \cdot 14 \mathrm{E}-12$ \\
\hline Sodium chloride & $1.21 \mathrm{E}-03$ & 8.97E-04 & $6 \cdot 68 \mathrm{E}-04$ & 0.18 & $2 \cdot 36 \mathrm{E}-14$ \\
\hline Dicalcium phosphate & $9.40 \mathrm{E}-03$ & $2 \cdot 68 \mathrm{E}-02$ & $3.63 E-04$ & 1.51 & $2 \cdot 91 \mathrm{E}-13$ \\
\hline Limestone & $1.31 \mathrm{E}-04$ & $1.03 \mathrm{E}-04$ & $3.58 \mathrm{E}-05$ & 0.02 & $2 \cdot 33 \mathrm{E}-15$ \\
\hline
\end{tabular}

eq, Equivalent; NRRU, non-renewable resource use; AP, acidification potential; EP, eutrophication potential; GWP, global warming potential; DDGS, dried distillers grains with solubles. * Inventory data for these ingredients was compiled as part of a previous life cycle assessment studies of Canadian pig farming systems ${ }^{(5,23)}$.

† Calculated by combining the total normalised NRRU, AP, EP and GWP using the Institute of Environmental Sciences at Leiden University methodology ${ }^{(39)}$ with equal weighting.

sources. A price ratio of 10:1 was assumed for bread and surplus material, with an average $10 \%$ of material collected as surplus from the bread supply chain either during the production process or discarded at the supermarket (Sugarich Ltd, unpublished results). Processing inputs for packaging removal, drying and grinding were estimated to be $20 \mathrm{kWh}$ electricity and $62 \mathrm{kWh}$ natural gas/tonne of material processed (Sugarich Ltd, unpublished results). LCI data for meat meal were adapted from a previous LCA study on rendering, and the yields by mass from rendering were assumed to be $57.7 \%$ for fat and $42.3 \%$ for meat meal ${ }^{(25)}$. The price ratio of rendered fat: meat meal was assumed to be $1.22^{(23)}$. The LCI data for wheat milling were adapted from Ecoinvent ${ }^{(22)}$ in order to represent Canadian energy inputs. Bread flour yields were estimated to be $73 \%$ on average, with remaining material flows of $2 \%$ wheat germ, $12.5 \%$ wheat shorts and $12 \%$ wheat $\operatorname{bran}^{(26)}$. A price ratio of 1:0·11:0·22:0.44 was assumed for wheat flour-wheat germ-wheat shorts-wheat bran. This was based on the expectation that flour would provide about $90 \%$ of the gross margin for a typical milling operation ${ }^{(27)}$ and Canadian price data for the co-products from wheat milling as animal feed ${ }^{(23)}$.

\section{Manure model}

The manure model estimated the emissions of $\mathrm{CH}_{4}, \mathrm{NH}_{3}, \mathrm{~N}_{2} \mathrm{O}, \mathrm{N}_{2}$ and $\mathrm{NO}_{x}$, which occurred during housing, storage and application as well as the leaching of $\mathrm{NO}_{3}$ and $\mathrm{PO}_{4}$. Indirect $\mathrm{N}_{2} \mathrm{O}$ formation resulting from $\mathrm{NH}_{3}$ and $\mathrm{NO}_{x}$ emissions and $\mathrm{NO}_{3}$ leaching was also modelled in accordance with the Intergovernmental Panel for Climate Change (IPCC) principles ${ }^{(28)}$. Manure was assumed to remain in the barn for up to $7 \mathrm{~d}$; it was then transferred to outside storage (except in cases where storage was a pit beneath the barn). Manure was expected to be applied to land twice annually in spring and autumn. The model of $\mathrm{NH}_{3}$ emissions for housing and storage was based on a previous model of $\mathrm{NH}_{3}$ emissions from pig production in Canada ${ }^{(29)}$. A tier 2 IPCC methodology was adopted for emissions of $\mathrm{CH}_{4}, \mathrm{~N}_{2} \mathrm{O}, \mathrm{NO}_{x}$ and $\mathrm{NO}_{3}$, but adapted to reflect small $\mathrm{N}$ losses from housing. As average ambient temperatures were considered to be $<0^{\circ} \mathrm{C}$ during winter ${ }^{(30)}$, emissions during this period were considered negligible for outside storage methods. The proportional mix of floor types in pig housing, storage and application techniques in each region was based on information from the Livestock Farm Practice Survey ${ }^{(29)}$, as well as Statistics Canada records regarding the storage and application of swine manure ${ }^{(31,32)}$. All $\mathrm{N}, \mathrm{P}$ and $\mathrm{K}$ excreted via faeces or urine were assumed to be applied to land as fertiliser, once losses during housing and storage were accounted for. Manure applied to land was assumed to replace the need to apply equivalent synthetic fertilisers at a rate of $0.75,0.97$ and 1 for $\mathrm{N}, \mathrm{P}$ and $\mathrm{K}$, respectively ${ }^{(33)}$. The proportional mixture of the types of synthetic fertilisers replaced by the NPK content of the manure in each region was derived from sales figures for Eastern and Western Canada to assume a regional average fertiliser $\mathrm{mix}^{(34)}$.

\section{Farm performance}

With the exception of feed intake during the G/F stage and carcass yield, the baseline herd performance characteristics (litter size, mortality, etc.) used in this study were as those modelled for pig systems in Eastern and Western Canada in a previous regional LCA study ${ }^{(5)}$. All characteristics of herd performance other than average feed intake and carcass yield were 
assumed to be independent of feed composition in the $\mathrm{G} / \mathrm{F}$ production stage ${ }^{(23)}$. Although this represents a simplification made for the purposes of a modelling exercise, it is valid for the scenarios modelled in this study. All diets formulated were nutritionally balanced and were not be expected to have implications on herd health status or mortality during the $G / F$ phase. It is reasonable to expect that other model inputs such as on-farm energy use are independent of feed composition. The on-farm energy consumption data were adapted from a detailed study of energy consumption in conventional pig housing systems in Iowa ${ }^{(35)}$, as there were no equivalent data for Canadian systems available. To reflect longer and colder Canadian winters in comparison with Mason City, Iowa (which was used in the Lammers et al. ${ }^{(35)}$ calculations), larger loads of liquid petroleum gas (LPG) for heating were assumed to be required to maintain adequate barn temperatures. On the basis of average temperature data for Mason City ${ }^{(36)}$, and regional data for Eastern and Western Canada ${ }^{(30)}$, the LPG inputs for heating barns in Eastern Canada were estimated to be $25 \%$ higher compared with the Iowa case study. LPG input for heating in Western Canada was assumed to be $25 \%$ larger than that for Eastern Canada. These represent approximations as a previous sensitivity analysis showed that the model was not very sensitive to the assumptions made regarding LPG use for any of the impact categories tested here ${ }^{(5)}$. The mix of electricity generation in the LCA was the national mix for the Canadian grid $^{(37)}$; this was assumed for all Canadian unit processes in the LCA.

\section{Quantifying environmental impacts}

The environmental impacts of the system were quantified by the LCA using four environmental impact categories. Three of these categories quantified negative impacts resulting from emissions caused by the system - AP, EP and GWP. We included GWP as it has received the most attention in efforts to quantify the impact of livestock systems. The impact categories $\mathrm{AP}$ and EP were considered as they quantify the main environmental impacts, which result from the storage and spreading of animal manure. The fourth impact category quantified the systems use of NRRU and was included because of the relatively high usage of cereals and oil seed meals in pig diets, which have a significant input of resources such as fertilisers ${ }^{(3)}$.

System GWP was quantified in $\mathrm{CO}_{2}$ equivalents (eq) on a 100-year timescale using the IPPC methodology ${ }^{(28)}$. The methodology of accounting for GWP caused by land use change in this study followed the PAS 2050 guidelines ${ }^{(38)}$. The methodologies for calculating AP ( $\mathrm{SO}_{2}$ eq), EP ( $\mathrm{PO}_{4}$ eq) and NRRU ( $\mathrm{Sb}$ eq) were established by researchers at the Institute of Environmental Sciences at Leiden University $(\mathrm{CML})^{(39)}$. This methodology was chosen as it is designed to quantify these impact categories on a global scale, importantly accounting for the long-term impacts of airborne emissions on global levels of substances, which contribute to AP and EP. The CML methodology for normalising different types of environmental impact $^{(40)}$ was also utilised to formulate diets to minimise the combined environmental impact score of the system. The impacts that result from a process are normalised against a reference, which is an estimate of the total annual level of global emissions and resource use caused by human activity ${ }^{(40)}$. The normalised scores for AP, EP, GWP and NRRU were then combined additively, with equal weighting to generate a combined environmental impact score in the diet formulation tool. Equal weighting was adopted in this example to ensure that large increases in an individual environmental impact category did not occur when optimising to minimise the combined environmental impact score. The cradle-to-grave environmental impact calculations were performed using the software package SimaPro 7.3.3.

\section{Diet formulation rules}

A diet formulation tool was developed that predicted the environmental impacts for each category resulting from $\mathrm{G} / \mathrm{F}$ diets for the feed supply chain and manure management. The tool also quantified the feed cost per $\mathrm{kg}$ LW gain for each solution. The tool formulated diets using linear programming in Microsoft Excel ${ }^{\circledR}$ with the software plug-in open solver ${ }^{(41)}$. Nutritional values for all ingredients in the diets were primarily taken from the Stein Monogastric Nutrition Laboratory ingredient matrix ${ }^{(42)}$. In cases where certain values were missing (or ingredients themselves were missing from the matrix), values from the NRC 2012 feed ingredient tables ${ }^{(43)}$ and the Premier Nutrition Atlas ${ }^{(44)}$ were used. All the G/F diets were formulated with four feeding phases (starter, grower, finisher and late finisher); this reflected typical feeding programmes adopted by commercial pig operations in Canada ${ }^{(5)}$.

The predicted start weight of the pigs in the diet formulation tool was fixed at $27.4 \mathrm{~kg}$ with a finish weight of $124 \mathrm{~kg}$ for the $\mathrm{G} / \mathrm{F}$ phase, based on benchmark data collected for a previous LCA study of Canadian pig farming ${ }^{(5)}$. Diets were not formulated for a fixed nutritional density, but rather this was an outcome of the solution for a specific objective. The average feed intake per pig for each diet within a feeding phase was predicted based on meeting the animal's requirements for growth. The net energy (NE) requirement for each feeding phase was defined in compliance with the NRC 2012 animal requirement tables ${ }^{(45)}$. Minimum nutrient levels in $\mathrm{g} / \mathrm{MJ}$ of $\mathrm{NE}$ were then defined for each feeding phase, so that the digestible protein and macronutrient contents of the feed would not be limiting for animal growth ${ }^{(45)}$. It was thus assumed that feed intake was driven by the animal's need to meet its daily energy requirements; as such feed intake increased when diets of reduced energy density were fed ${ }^{(46,47)}$. The average predicted $\mathrm{NE}$ intake was constant for all diets. As all diets were nutritionally balanced, the animals were expected to spend the same average number of days in the barn over the course of the $\mathrm{G} / \mathrm{F}$ phase. When diets were formulated at reduced energy density, daily feed intake was expected to compensate for this. Any effects the increased daily intake may have had on gut fill were taken into account ${ }^{(23)}$.

Average ingredient prices and availability in Ontario and Manitoba for 2015 were provided by Trouw Nutrition (derived from Statistics Canada data ${ }^{(48)}$ - see online Supplementary Material S2 for the list of available ingredients and price ratios in each region). These were used to represent typical diet formulation scenarios for Eastern and Western Canada. 
Table 2. The nutritional specifications of the 'typical' grower/finisher diet for Canadian pig systems*

\begin{tabular}{|c|c|c|c|c|c|c|c|c|}
\hline \multirow[b]{2}{*}{ Resource ( $\mathrm{g} / \mathrm{kg}$ unless otherwise stated) } & \multicolumn{2}{|c|}{ Starter } & \multicolumn{2}{|c|}{ Grower } & \multicolumn{2}{|c|}{ Finisher } & \multicolumn{2}{|c|}{ Late finisher } \\
\hline & Typical & Lower limit & Typical & Lower limit & Typical & Lower limit & Typical & Lower limit \\
\hline Net energy (MJ/kg) & $10 \cdot 21$ & $9 \cdot 70$ & 9.89 & 9.40 & 9.72 & 8.99 & $9 \cdot 65$ & 8.93 \\
\hline Digestible crude protein & $156 \cdot 3$ & 148.5 & 140.5 & 133.5 & $122 \cdot 9$ & $113 \cdot 7$ & $110 \cdot 1$ & $101 \cdot 8$ \\
\hline Digestible Arg & $10 \cdot 5$ & $10 \cdot 0$ & 8.8 & 8.3 & $7 \cdot 2$ & $6 \cdot 7$ & $6 \cdot 3$ & $5 \cdot 8$ \\
\hline Digestible His & 4.7 & 4.4 & 4.1 & 3.9 & 3.5 & $3 \cdot 2$ & 3.1 & $2 \cdot 9$ \\
\hline Digestible lle & $6 \cdot 1$ & $5 \cdot 8$ & 5.3 & $5 \cdot 1$ & 4.6 & 4.3 & 4.0 & 3.7 \\
\hline Digestible Leu & $12 \cdot 8$ & $12 \cdot 1$ & $12 \cdot 1$ & 11.5 & 11.4 & $10 \cdot 5$ & $10 \cdot 4$ & 9.6 \\
\hline Digestible Lys & $10 \cdot 4$ & 9.9 & $9 \cdot 2$ & $8 \cdot 7$ & $7 \cdot 3$ & $6 \cdot 8$ & 6.5 & $6 \cdot 0$ \\
\hline Digestible Met & $3 \cdot 2$ & 3.0 & $2 \cdot 7$ & $2 \cdot 6$ & 2.5 & $2 \cdot 3$ & $2 \cdot 2$ & $2 \cdot 0$ \\
\hline Digestible Phe & $7 \cdot 2$ & $6 \cdot 8$ & $6 \cdot 4$ & $6 \cdot 1$ & 5.7 & $5 \cdot 3$ & $5 \cdot 1$ & 4.7 \\
\hline Digestible Thr & $6 \cdot 3$ & $6 \cdot 0$ & 5.8 & 5.5 & 4.9 & 4.5 & 4.4 & $4 \cdot 1$ \\
\hline Digestible Trp & 1.7 & 1.6 & 1.5 & 1.4 & 1.2 & $1 \cdot 1$ & 1.1 & 1.0 \\
\hline Digestible Val & $7 \cdot 3$ & 6.9 & 6.5 & $6 \cdot 2$ & $5 \cdot 8$ & 5.4 & $5 \cdot 1$ & 4.7 \\
\hline Digestible Cys & $2 \cdot 7$ & $2 \cdot 6$ & 2.7 & $2 \cdot 6$ & 2.5 & $2 \cdot 3$ & $2 \cdot 3$ & $2 \cdot 1$ \\
\hline Digestible Met + Cys & 5.9 & $5 \cdot 6$ & 5.5 & $5 \cdot 2$ & $5 \cdot 1$ & 4.7 & 4.5 & $4 \cdot 2$ \\
\hline $\mathrm{Ca}$ & $7 \cdot 6$ & $7 \cdot 2$ & $7 \cdot 6$ & $7 \cdot 2$ & $6 \cdot 7$ & $6 \cdot 2$ & 5.9 & 5.5 \\
\hline $\mathrm{P}$ & 5.5 & $5 \cdot 2$ & $5 \cdot 3$ & $5 \cdot 0$ & $4 \cdot 6$ & $4 \cdot 3$ & $4 \cdot 1$ & 3.8 \\
\hline Digestible P & $3 \cdot 1$ & 2.9 & $2 \cdot 8$ & $2 \cdot 7$ & $2 \cdot 3$ & $2 \cdot 1$ & 1.9 & 1.8 \\
\hline $\mathrm{K}$ & $6 \cdot 6$ & $6 \cdot 3$ & $6 \cdot 2$ & 5.9 & 5.6 & $5 \cdot 2$ & 5.0 & 4.6 \\
\hline
\end{tabular}

* The lower limits permitted in the diet formulation rules used in this study are also shown.

Ontario and Manitoba produced about 24 and $23 \%$ of the total pigs marketed in Canada in 2011, respectively ${ }^{(49)}$. Importantly, maize was not considered as an available ingredient in the Western diets as is typical in many scenarios in this region; similarly, barley was not considered as an available ingredient in the Eastern diets (A Pharazyn, unpublished results).

The average gain:feed ratio over the $G / F$ phase in the benchmark data for Canadian pigs was $0 \cdot 365^{(5)}$ with feed intake of $264 \mathrm{~kg} / \mathrm{pig}$ based on the mean start and finish weights. This was used as a starting point for the assumptions on average feed intake in this study. A dietary specification was defined, which represented an industry standard to ensure that the feed: LW gain ratio was minimised within reasonable commercial constraints. The specifications for this 'typical' diet are given in Table 2, and it was assumed that this diet ensured an average gain:feed ratio of 0.365 . Lower limits were defined for the nutritional density of the diets for each feeding phase. These were set at $95 \%$ of the energy content of the typical industry diet in the first two feeding phases and at $92.5 \%$ for the latter two feeding phases. These restrictions were to ensure that feed intake would not be restricted by gut fill, which can be caused by diets of lower nutrient density, which contain a larger proportion of bulky feed ${ }^{(46)}$. These minimum specifications of the $\mathrm{G} / \mathrm{F}$ diet for each phase can also be found in Table 2. For each ingredient, a maximum inclusion rate was defined for each feeding phase in order to account for any anti-nutritional properties or other negative impacts on animal performance due to variability. These limits were based on guidance for pig farmers provided by the Ontario Ministry of Agriculture, Food and Rural Affairs ${ }^{(50)}$ as well as peer-reviewed studies in the case of some important co-products ${ }^{(23)}$ (see online Supplementary Material S3 for further details on ingredient inclusion limits).

The retention of $\mathrm{N}$ in finished pigs was calculated using the principles of Wellock et al. $^{(51)}$ and was assumed to be 0.0256 (SD 0.00128) body weight (BW). Retentions of $\mathrm{P}$ and $\mathrm{K}$ were calculated using an isometric relationship of body composition with $\mathrm{BW}^{(52)}$ and were assumed to be approximately 0.005 (sD 0.00025) and 0.002 (sD 0.0001) BW, respectively. For K, this assumption represents a linear approximation around slaughter weight of a curvilinear relationship ${ }^{(53)}$. All $\mathrm{N}, \mathrm{P}$ and $\mathrm{K}$ not retained by the finished pigs were assumed to be excreted via faeces or urine. The predicted levels of nutrient excretion were required as inputs to the manure model.

\section{Diets formulated}

The process followed to formulate $\mathrm{G} / \mathrm{F}$ diets for environmental impact objectives is shown as part of Fig. 2. The average values of NRRU, AP, EP and GWP $/ \mathrm{kg}$ of each ingredient as seen in Table 1 were added to the list of ingredient properties in the diet formulation tool. In addition to this, equations that predicted the average environmental impact per $\mathrm{kg}$ of $\mathrm{N}, \mathrm{P}$ and $\mathrm{K}$ excretion assuming an average mix of manure management practices were extracted from the manure sub-model of the $\mathrm{LCA}^{(5)}$. This enabled the tool to account for the environmental impact resulting from predicted levels of nutrient excretion when formulating the diets. Thus, for any diet formulated, the average values of NRRU, AP, EP and GWP resulting from the feed supply chain and manure storage and application were predicted.

The tool was used to formulate G/F diets for both economic and environmental impact objectives. Two diets were formulated for economic objectives: (1) to minimise feed cost per $\mathrm{kg} \mathrm{LW}$ gain (least cost) and (2) to minimise feed cost per kg LW gain with a requirement to maintain a certain level of feed efficiency (least-cost EFF). The NE content of the latter diet was fixed, so that the feed:LW gain ratio was minimised within reasonable commercial constraints. The minimum specifications of this diet were the 'industry standard' energy and nutrient levels shown in Table 2. This is a common commercial scenario, 


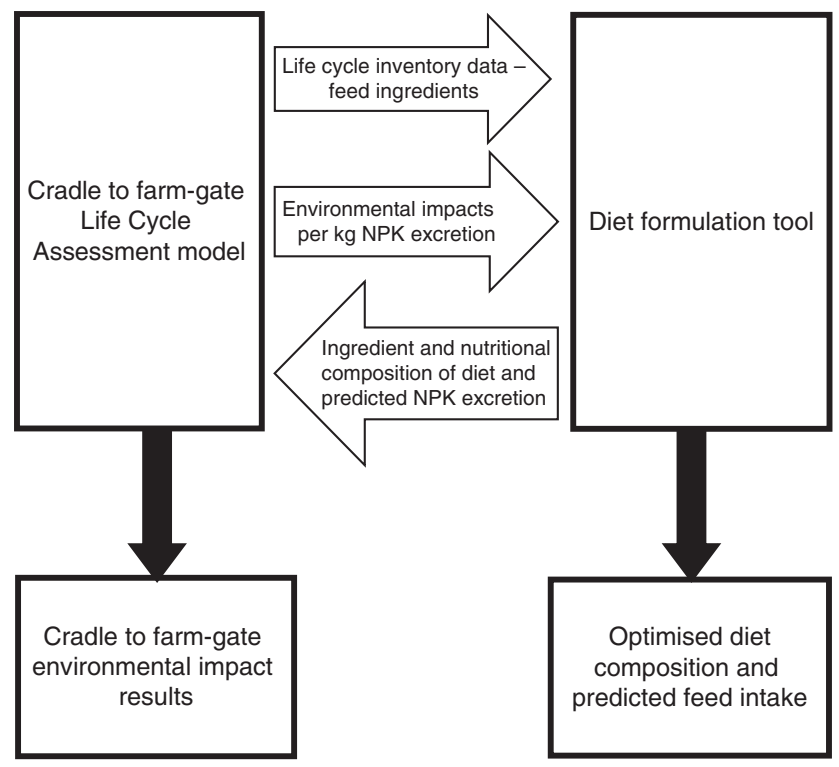

Fig. 2. Schematic of the methodology followed in this study to formulate diets for environmental impact objectives.

whereby diets are formulated for least cost without compromising feed efficiency ${ }^{(1)}$. This diet was included to quantify whether this strategy has any benefit for the environmental impact of the system compared with considering feed cost alone.

Four diets were formulated to minimise the individual environmental impact categories NRRU, AP, EP and GWP. A further diet was formulated to minimise the combined environmental impact (least EI) of the G/F phase, as measured using the combined normalised levels of NRRU, AP, EP and GWP under the CML methodology ${ }^{(39)}$ with equal weighting. All diets formulated for environmental impact objectives were restricted to a $30 \%$ maximum cost increase in comparison with the least cost diet. Diets were formulated for these objectives in both regional scenarios for ingredient prices and ingredient availability for Eastern and Western Canada. Diets were formulated using linear programming. The resulting diets were optimal solutions based on the mean nutritional and environmental impact properties of the ingredients, as well as the mean impact levels associated with nutrient excretion calculated by the LCA.

\section{Dietary comparisons in the life cycle assessment model}

Accounting for the uncertainty in LCA is important to produce credible and reliable results ${ }^{(54)}$. In this study, an uncertainty analysis was used for statistical comparison of the diet formulations. The cradle to farm gate LCA model was hosted in the specialist software SimaPro. All input parameters had a mean, associated distribution (e.g. normal, lognormal, etc.) and standard deviation. The uncertainty in the environmental impact calculations was quantified using Monte Carlo simulations ${ }^{(5)}$. Variability in all characteristics of herd performance other than feed intake was assumed to be independent of feed composition in the $G / F$ production stage. Feed intake for each simulation was a function of the energy density of the diet in relation to the average energy requirement of the herd over the $\mathrm{G} / \mathrm{F}$ production stage. This requirement had a distribution to represent variation in feed intake due to genetic and environmental factors, which were assumed to be independent of the feed composition.

As shown in Fig. 2, each diet was tested in the cradle to farm gate LCA of pig farming systems in Eastern and Western Canada. In each case, 1000 simulations of the model were run in order to calculate the NRRU, AP, EP and GWP of the system when adopting these diets. This number of simulations ensured that the SEM of the results for each impact category were low enough for good repeatability ${ }^{(5)}$. Parallel Monte Carlo simulations were used to compare all other diets with the least-cost diet. The parallel simulations enabled the model to determine whether the diets had resulted in any significant changes to the environmental impact levels of the system compared with the least-cost scenario. This method of uncertainty analysis to distinguish between two scenarios in an LCA model was described in detail by Mackenzie et $a l .{ }^{(5)}$. In brief, uncertainties were categorised as either specific to the system $(\alpha)$ or shared between the systems being compared $(\beta)^{(55,56)}$. For each simulation, a value for each parameter was randomly selected from the specified distribution input for this variable. Where parameters are shared between two scenarios being tested (e.g. maize yield ( $\mathrm{kg} / \mathrm{ha}$ ) when feeding two different diets containing maize), for each individual comparison the same point on the distribution is selected. In this case, variations in all parameters except the $\mathrm{G} / \mathrm{F}$ diet composition, the resulting feed intake and nutrient excretion during the G/F phase and carcass yield were considered as shared uncertainty in the comparisons. Although the average energy requirement was variable to account for differences caused by animal and environmental factors, in each comparison, the NE intake was the same for both diets. The key output of the simulations was the frequency in which the environmental impact of one scenario was greater or smaller than the second scenario for each impact category tested. Environmental impact levels were reported as significantly different in cases where $P<0.05$ over 1000 parallel simulations of the LCA model. This allowed the model to account for shared uncertainty between two systems (in this case diets) modelled in the LCA, but provide a useful answer as to which is likely to have greater environmental impact.

\section{Results}

\section{Diet composition}

The overall ingredients and nutritional composition of the diets formulated for Eastern and Western Canada are in Tables 3 and 4 , respectively, along with the predicted feed cost and average feed intake per pig for each diet. For both regional scenarios, the least-cost diet had the lowest nutritional density, and thus the highest average predicted feed intake over the $\mathrm{G} / \mathrm{F}$ cycle of the diets formulated. The least-cost EFF diet minimised feed intake (by design) and was cheaper per kg LW than all diets formulated for environmental impact objectives. 
Table 3. The overall ingredients and nutritional composition (across all four feeding phases) of the grower/finisher diets formulated for different objectives for Eastern Canada*

\begin{tabular}{|c|c|c|c|c|c|c|c|}
\hline Objectives & Least cost & Least-cost EFF & Least NRRU & Least AP & Least EP & Least GWP & Least El \\
\hline Average feed cost (CAD/kg live weight gain) & 0.544 & 0.562 & 0.708 & 0.610 & 0.591 & 0.708 & 0.611 \\
\hline Average feed consumed $(\mathrm{kg} / \mathrm{pig})$ & 280.5 & 264.0 & $275 \cdot 8$ & 265.4 & 272.5 & $264 \cdot 0$ & 264.0 \\
\hline \multicolumn{8}{|l|}{ Ingredients } \\
\hline Rapeseed meal & $42 \cdot 77$ & 51.05 & $100 \cdot 00$ & 95.69 & $96 \cdot 39$ & 0.00 & $71 \cdot 18$ \\
\hline Maize & 574.99 & $706 \cdot 29$ & $232 \cdot 13$ & 443.17 & 580.35 & 237.67 & 480.57 \\
\hline Maize DDGS & 36.79 & 0.00 & 0.00 & 113.88 & 53.10 & 0.00 & 0.00 \\
\hline Meat meal & 0.00 & 0.00 & 39.83 & 0.00 & 0.00 & 40.99 & 0.00 \\
\hline Bakery meal & 0.00 & 0.00 & 94.01 & 94.08 & 94.24 & 94.05 & 94.05 \\
\hline Soyameal high protein & 88.67 & $169 \cdot 88$ & $250 \cdot 00$ & 46.51 & $62 \cdot 38$ & $250 \cdot 00$ & $109 \cdot 81$ \\
\hline Wheat & 0.00 & 0.00 & 0.00 & 0.00 & 25.63 & 0.00 & 0.00 \\
\hline Wheat bran & 0.00 & 0.00 & 0.00 & $50 \cdot 00$ & 50.00 & 50.00 & 50.00 \\
\hline Wheat shorts & 231.29 & $45 \cdot 11$ & 261.53 & 86.64 & 0.00 & $260 \cdot 60$ & $136 \cdot 25$ \\
\hline Limestone & 13.46 & $12 \cdot 40$ & 13.06 & 22.48 & 19.78 & 26.52 & 22.03 \\
\hline Dicalcium phosphate & 0.86 & 3.73 & 0.00 & 0.54 & 2.09 & 0.00 & 0.29 \\
\hline $\mathrm{NaCl}$ & 4.22 & 4.77 & 2.41 & 3.22 & 2.92 & 3.19 & 3.41 \\
\hline Lys $\mathrm{HCl}$ & $2 \cdot 35$ & 0.86 & 0.00 & 3.70 & 3.35 & 0.00 & $2 \cdot 18$ \\
\hline DL-Met & 0.11 & 0.06 & 0.00 & 0.12 & 0.15 & 0.02 & 0.22 \\
\hline L-Thr & 0.48 & 0.08 & 0.00 & 0.80 & 0.81 & 0.00 & 0.57 \\
\hline L-Try & 0.00 & 0.00 & 0.00 & 0.02 & 0.01 & 0.00 & 0.00 \\
\hline Soya oil & 0.00 & 0.00 & 0.00 & 0.00 & 0.00 & 19.00 & $15 \cdot 81$ \\
\hline $\mathrm{AV}$ fat blend & 0.00 & 1.49 & 2.96 & 34.91 & 4.68 & $13 \cdot 70$ & $9 \cdot 37$ \\
\hline Additives & 4.01 & 4.26 & 4.08 & 4.24 & $4 \cdot 13$ & 4.26 & $4 \cdot 26$ \\
\hline \multicolumn{8}{|l|}{ Resources } \\
\hline Net energy $(\mathrm{MJ} / \mathrm{kg})$ & 9.24 & $9 \cdot 82$ & 9.39 & 9.77 & 9.51 & 9.82 & 9.82 \\
\hline Digestible CP & $127 \cdot 7$ & $145 \cdot 2$ & $213 \cdot 7$ & $128 \cdot 7$ & $125 \cdot 5$ & 192.5 & $134 \cdot 7$ \\
\hline Digestible Arg & 8.6 & $10 \cdot 1$ & $16 \cdot 3$ & 7.8 & 7.6 & $14 \cdot 8$ & 9.2 \\
\hline Digestible His & 4.0 & 4.8 & $7 \cdot 0$ & 3.7 & 3.7 & $6 \cdot 3$ & $4 \cdot 2$ \\
\hline Digestible lle & 5.0 & 6.0 & 9.0 & 4.8 & 4.7 & $8 \cdot 1$ & $5 \cdot 3$ \\
\hline Digestible Leu & 11.7 & $13 \cdot 3$ & $16 \cdot 8$ & $12 \cdot 0$ & 11.6 & $15 \cdot 3$ & 11.5 \\
\hline Digestible Lys & 7.5 & 8.0 & 11.8 & 8.0 & $7 \cdot 8$ & 10.5 & 8.0 \\
\hline Digestible Met & $2 \cdot 4$ & $2 \cdot 6$ & 3.6 & $2 \cdot 6$ & 2.5 & $3 \cdot 1$ & $2 \cdot 6$ \\
\hline Digestible Phe & $6 \cdot 2$ & $7 \cdot 2$ & $10 \cdot 3$ & $6 \cdot 0$ & $5 \cdot 8$ & 9.4 & 6.4 \\
\hline Digestible Thr & 4.9 & $5 \cdot 2$ & $7 \cdot 6$ & $5 \cdot 1$ & $5 \cdot 0$ & $6 \cdot 7$ & $5 \cdot 2$ \\
\hline Digestible Trp & 1.4 & 1.6 & 2.7 & 1.3 & 1.3 & $2 \cdot 4$ & 1.6 \\
\hline Digestible Val & $6 \cdot 2$ & 6.9 & 10.5 & $6 \cdot 1$ & $5 \cdot 8$ & 9.4 & 6.4 \\
\hline Digestible Cys & $2 \cdot 4$ & $2 \cdot 6$ & 3.6 & 2.5 & 2.5 & $3 \cdot 1$ & 2.6 \\
\hline Digestible Met + Cys & 4.9 & $5 \cdot 2$ & $7 \cdot 2$ & $5 \cdot 1$ & $5 \cdot 0$ & $6 \cdot 2$ & $5 \cdot 1$ \\
\hline $\mathrm{Ca}$ & 6.5 & 6.9 & 9.9 & $10 \cdot 2$ & 9.4 & 14.5 & $10 \cdot 0$ \\
\hline $\mathrm{P}$ & $5 \cdot 2$ & 4.8 & $7 \cdot 8$ & $5 \cdot 1$ & 4.7 & $7 \cdot 3$ & 5.0 \\
\hline Digestible $\mathrm{P}$ & $2 \cdot 7$ & $2 \cdot 5$ & 4.4 & 2.6 & $2 \cdot 3$ & 4.2 & $2 \cdot 4$ \\
\hline $\mathrm{K}$ & 7.0 & $6 \cdot 7$ & 10.5 & 6.5 & $5 \cdot 8$ & 9.8 & 6.9 \\
\hline Gross energy $(\mathrm{MJ} / \mathrm{kg})$ & $16 \cdot 7$ & $16 \cdot 3$ & $17 \cdot 3$ & $17 \cdot 4$ & 16.4 & 17.6 & $17 \cdot 0$ \\
\hline $\mathrm{CP}$ & 165.5 & 175.4 & 271.3 & $166 \cdot 3$ & $156 \cdot 6$ & 242.5 & 170.4 \\
\hline Ash & 45.5 & $42 \cdot 2$ & $60 \cdot 7$ & 57.6 & 52.4 & 69.8 & 57.9 \\
\hline
\end{tabular}

Least cost, least feed cost per kg live weight gain; least-cost EFF, least cost/kg live weight gain while maximising feed efficiency within commercial constraints; NRRU, non-renewable resource use; AP, acidification potential; EP, eutrophication potential; GWP, global warming potential; HP, high protein; least EI, least combined environmental impact score; CP, crude protein; CAD, Canadian dollars; DDGS, dried distillers grains with solubles; AV, animal-vegetable.

${ }^{*}$ All ingredient inclusion and nutrient levels shown are $\mathrm{g} / \mathrm{kg}$ as fed unless otherwise stated. The average predicted feed intake and feed costs for each grower/finisher diet are also shown.

Of the diets formulated for environmental impact objectives, the least-NRRU diets were the most expensive in both regions, resulting in a $30 \%$ increase in feed cost in comparison with the least-cost diet. The least-GWP diets also resulted in large increases in feed cost per $\mathrm{kg} \mathrm{LW}$ of 30 and $23 \%$ in the East and West Canadian scenarios, respectively. The least-NRRU and least-GWP diets raised feed costs significantly owing to increased inclusions of relatively expensive protein meals (soyameal and rapeseed meal). The least-AP diet increased feed costs by $12 \%$ in Eastern Canada and $16 \%$ in Western Canada compared with the least-cost diet. The least-EI diets were $12 \%$ more expensive than the least-cost diet in both regions. The least-EP diet was the cheapest of the diets formulated for environmental impact objectives, increasing feed costs by 8 and $6 \%$ compared with the least-cost diet in Eastern and Western Canada, respectively.

In both regions, the least-GWP diet was the most energy dense of all the diets formulated for environmental impact objectives (along with the least-EI diet in the East), with feed intake being the same as the least-cost EFF diet. The West Canadian least-EI diet was less energy dense, and thus average feed intake per pig was higher at $274 \mathrm{~kg}$ in comparison with $264 \mathrm{~kg} / \mathrm{pig}$ in the Eastern scenario. The least-EP diet reduced average feed intake by $3 \%$ in the Eastern scenario and $6 \%$ reduced average feed intake in the West. Compared with the least-cost diet, average feed intake was 5\% lower for the 
Table 4. The overall ingredients and nutritional composition (across all four feeding phases) of grower/finisher diets formulated for different objectives for Western Canada*

\begin{tabular}{|c|c|c|c|c|c|c|c|}
\hline Objectives & Least cost & Least-cost EFF & Least NRRU & Least AP & Least EP & Least GWP & Least El \\
\hline Average feed cost (CAD/kg live weight gain) & 0.536 & 0.550 & 0.690 & 0.623 & 0.567 & 0.656 & 0.599 \\
\hline Average feed consumed (kg/pig) & $283 \cdot 1$ & $264 \cdot 0$ & 271.4 & $272 \cdot 2$ & $266 \cdot 4$ & $264 \cdot 4$ & $274 \cdot 4$ \\
\hline \multicolumn{8}{|l|}{ Ingredients } \\
\hline Barley & 0.00 & 0.00 & 0.00 & $579 \cdot 38$ & 0.00 & 353.32 & 489.80 \\
\hline Rapeseed meal & 38.61 & 52.00 & 77.97 & 3.05 & 0.00 & 61.03 & 0.00 \\
\hline Maize DDGS & 83.09 & $112 \cdot 34$ & 0.00 & $179 \cdot 26$ & 145.46 & 0.00 & 164.05 \\
\hline Meat meal & 0.00 & 0.00 & 1.01 & 0.00 & 0.00 & 0.27 & 0.00 \\
\hline Field peas & $100 \cdot 00$ & $100 \cdot 00$ & $100 \cdot 00$ & $13 \cdot 81$ & 0.00 & 0.00 & $12 \cdot 05$ \\
\hline Soyameal HP & 5.40 & 13.95 & $250 \cdot 00$ & 59.35 & 34.67 & $250 \cdot 00$ & 57.03 \\
\hline Wheat & 553.94 & 606.49 & $279 \cdot 81$ & 0.00 & $518 \cdot 81$ & 0.00 & 0.00 \\
\hline Wheat bran & 0.00 & 0.00 & 0.00 & $42 \cdot 80$ & 0.00 & 0.00 & 0.00 \\
\hline Wheat shorts & 177.93 & 48.82 & 261.53 & 37.67 & $209 \cdot 32$ & 260.49 & $190 \cdot 87$ \\
\hline Limestone & $12 \cdot 59$ & 11.67 & $11 \cdot 21$ & $21 \cdot 75$ & 25.52 & 22.03 & $24 \cdot 12$ \\
\hline Dicalcium phosphate & $2 \cdot 71$ & $6 \cdot 11$ & 0.00 & 0.55 & 2.40 & 0.00 & 0.21 \\
\hline $\mathrm{NaCl}$ & 3.97 & $4 \cdot 14$ & 4.54 & 3.65 & $4 \cdot 10$ & 4.69 & 3.57 \\
\hline Lys $\mathrm{HCl}$ & $2 \cdot 94$ & 3.44 & 0.00 & 3.60 & 4.50 & 0.00 & 3.35 \\
\hline DL-Met & 0.05 & 0.08 & 0.00 & 0.19 & 0.13 & 0.00 & 0.15 \\
\hline L-Thr & 0.47 & 0.66 & 0.00 & 0.77 & 0.88 & 0.00 & 0.68 \\
\hline L-Try & 0.00 & 0.00 & 0.00 & 0.04 & 0.00 & 0.00 & 0.01 \\
\hline Soya oil & 0.00 & 0.00 & 0.00 & 7.80 & 14.55 & 0.00 & $20 \cdot 00$ \\
\hline $\mathrm{AV}$ fat blend & $14 \cdot 30$ & 36.07 & $9 \cdot 82$ & $42 \cdot 20$ & 35.45 & 43.91 & 30.00 \\
\hline Additives & 4.00 & 4.26 & $4 \cdot 10$ & $4 \cdot 14$ & 4.23 & 4.26 & $4 \cdot 10$ \\
\hline \multicolumn{8}{|l|}{ Resources } \\
\hline Net energy (MJ/kg) & $9 \cdot 20$ & 9.82 & 9.55 & 9.52 & 9.79 & $9 \cdot 80$ & 9.45 \\
\hline Digestible CP & 139.6 & $145 \cdot 2$ & 238.8 & $134 \cdot 2$ & $138 \cdot 6$ & $196 \cdot 3$ & $132 \cdot 8$ \\
\hline Digestible Arg & 8.5 & 8.4 & $18 \cdot 1$ & $7 \cdot 6$ & $7 \cdot 8$ & 14.7 & 8.0 \\
\hline Digestible His & 3.7 & 3.8 & $7 \cdot 6$ & 3.6 & 3.7 & $6 \cdot 4$ & 3.7 \\
\hline Digestible Ile & $5 \cdot 2$ & 5.4 & $10 \cdot 0$ & 4.8 & $5 \cdot 1$ & 8.2 & $4 \cdot 8$ \\
\hline Digestible Leu & $10 \cdot 8$ & 11.5 & $17 \cdot 6$ & 11.1 & 11.4 & 14.4 & 11 \\
\hline Digestible Lys & 7.5 & 8.0 & 13.4 & $7 \cdot 8$ & 7.9 & $10 \cdot 7$ & $7 \cdot 7$ \\
\hline Digestible Met & $2 \cdot 4$ & $2 \cdot 6$ & 3.8 & $2 \cdot 5$ & $2 \cdot 6$ & 3.1 & 2.5 \\
\hline Digestible Phe & $6 \cdot 7$ & $7 \cdot 0$ & 11.5 & 6.5 & $6 \cdot 8$ & 9.7 & 6.5 \\
\hline Digestible Thr & 4.8 & $5 \cdot 2$ & 8.4 & $5 \cdot 0$ & $5 \cdot 1$ & 6.9 & $5 \cdot 0$ \\
\hline Digestible Trp & 1.5 & 1.6 & 3.0 & 1.3 & 1.5 & 2.5 & 1.3 \\
\hline Digestible Val & $6 \cdot 4$ & 6.5 & 11.4 & $6 \cdot 2$ & $6 \cdot 4$ & 9.5 & $6 \cdot 3$ \\
\hline Digestible Cys & 3.0 & $3 \cdot 1$ & 4.2 & $2 \cdot 5$ & $2 \cdot 9$ & 3.4 & 2.5 \\
\hline Digestible Met + Cys & $5 \cdot 4$ & 5.7 & $8 \cdot 1$ & $5 \cdot 0$ & 5.5 & $6 \cdot 5$ & $4 \cdot 9$ \\
\hline $\mathrm{Ca}$ & $6 \cdot 4$ & 6.9 & 6.7 & 9.5 & $11 \cdot 2$ & $10 \cdot 6$ & $10 \cdot 3$ \\
\hline $\mathrm{P}$ & $5 \cdot 6$ & $5 \cdot 7$ & 7.4 & 4.8 & $5 \cdot 6$ & $6 \cdot 2$ & $5 \cdot 2$ \\
\hline Digestible P & $2 \cdot 3$ & $2 \cdot 4$ & 3.5 & $2 \cdot 5$ & $2 \cdot 4$ & $3 \cdot 1$ & $2 \cdot 8$ \\
\hline $\mathrm{K}$ & 7.0 & 6.4 & 11.3 & $7 \cdot 1$ & $7 \cdot 1$ & $10 \cdot 4$ & $7 \cdot 7$ \\
\hline Gross energy $(\mathrm{MJ} / \mathrm{kg})$ & $16 \cdot 5$ & $16 \cdot 7$ & $17 \cdot 3$ & $17 \cdot 6$ & $17 \cdot 3$ & $17 \cdot 8$ & $17 \cdot 8$ \\
\hline $\mathrm{CP}$ & $179 \cdot 3$ & 180.9 & $297 \cdot 7$ & $170 \cdot 1$ & $178 \cdot 1$ & $246 \cdot 3$ & 174.4 \\
\hline Ash & $45 \cdot 2$ & 43.4 & 53.2 & $51 \cdot 6$ & $57 \cdot 3$ & $64 \cdot 3$ & $56 \cdot 7$ \\
\hline
\end{tabular}

Least cost, least feed cost per kg live weight gain; least-cost EFF, least cost/kg live weight gain while maximising feed efficiency within commercial constraints; NRRU, non-renewable resource use; AP, acidification potential; EP, eutrophication potential; GWP, global warming potential; least El, least combined environmental impact score; $\mathrm{HP}$, high protein; CP, crude protein; CAD, Canadian dollars; DDGS, dried distillers grains with solubles; AV, animal-vegetable.

* All ingredient inclusion and nutrient levels shown are $\mathrm{g} / \mathrm{kg}$ as fed unless otherwise stated. The average predicted feed intake and feed costs for each grower/finisher diet are also shown.

least-AP diet in the East Canadian scenario and $4 \%$ in the West. The least-NRRU diets were the least nutritionally dense of the environmental impact objective diets with feed intake $2 \%$ lower in the East and $4 \%$ lower in the West in comparison with the least-cost diet.

The least-cost EFF diet contained the largest amount of cereals (maize in the East and wheat/barley in the West) of all diets formulated. In both regions, this diet contained the lowest levels of co-products (such as maize DDGS and wheat shorts), as well as an increased combined inclusion of oilseed meals (rapeseed meal and soyameal), compared with the least-cost diet. All diets formulated for environmental impact objectives in Eastern Canada included the maximum allowed levels of bakery meal in the G/F diets. Similarly, with the exception of the least-NRRU diet, all diets formulated for environmental impact objectives in Eastern Canada contained the maximum amount of wheat bran. This was not the case for the wheat/barley-based diets formulated in Western Canada.

In both regions, the least-NRRU diet contained the lowest combined inclusion of whole cereals (wheat, barley and maize). The least-NRRU diet contained no synthetic amino acid supplements or maize DDGS in either region. In both regions, the least-GWP and least-NRRU diets were very similar: both contained high levels of wheat shorts and, in the East, bakery meal and meat meal. There was also an increased inclusion of soyameal in the least-GWP diets with very little synthetic amino acid supplementation compared with the leastcost formulation. 


\section{Environmental impacts: Eastern Canada}

The environment impact results per kg of ECW from cradle to farm gate for the East Canadian diets when tested in the LCA model are given in Table 5. The relative trade-offs of diets formulated for different objectives in terms of environmental impact, feed cost and feed intake are shown in Fig. 3 for Eastern Canada. The least-cost EFF diet reduced NRRU and GWP by 8 and $3 \%$, respectively, compared with the least-cost diet; levels of AP and EP were not significantly different between these two scenarios. The combined environmental impact score of the least-cost EFF diet was marginally lower than the least-cost diet by $<1 \%$.

Reductions in NRRU (48\%), AP (5\%), EP (6\%) and GWP (17\%) were made when diets were formulated to minimise these impact categories in comparison with the least-cost diet. The maximum reduction achieved in the combined environmental impact score was $5 \%$ when optimising the $\mathrm{G} / \mathrm{F}$ diets for this objective compared with the least-cost diet. In each case, diets aimed at minimising the individual environmental impact categories resulted in increases in some of the other impact categories tested, compared with the least-cost diet. The least-NRRU diet also reduced GWP by $14 \%$, but increased AP and EP by 46 and $49 \%$, respectively. Similarly, the least-GWP diet reduced NRRU by $44 \%$ but increased AP by $26 \%$ and EP by $28 \%$. The least-AP diet increased NRRU by $19 \%$, whereas EP was reduced by $5 \%$ with no significant qdifference in GWP. The least-EP diet also meant that AP was 5\% lower; however, NRRU and GWP increased by 13 and 3\%, respectively. The least-EI diet did not increase any of the four environmental impact categories tested - the only diet formulated to achieve this.

\section{Environmental impacts: Western Canada}

The environment impact results per $\mathrm{kg}$ of ECW from cradle to farm gate for the diets in Western Canada when tested in the LCA model are in Table 6 . The relative trade-offs of diets formulated for different objectives in terms of environmental impact, feed cost and feed intake are shown in Fig. 4 for Western Canada. The least cost EFF diet resulted in a $6 \%$ increase in NRRU and $4 \%$ lower levels of AP, whereas EP and GWP did not change. The combined environmental impact score of the least-cost EFF diet was 3\% lower than the least-cost diet.

Reductions in NRRU (46\%), AP (17\%), EP (10\%) and GWP (24\%) were made when diets were formulated to minimise these impact categories in comparison with the least-cost diet. A $7 \%$ reduction was made in the combined environmental impact score per $\mathrm{kg}$ of $\mathrm{ECW}$ when this was the objective. Diets optimised to minimise the individual environmental impact categories resulted in increases in some of the other impact categories tested, compared with the least-cost diet. The least-NRRU diet also reduced GWP by $19 \%$ but increased AP and EP by $28 \%$. Similarly the least-GWP diet increased AP by $8 \%$, EP by $16 \%$ with NRRU reduced by $37 \%$ compared with the least-cost diet. The least-AP diet increased NRRU by $28 \%$ and did not significantly alter EP or GWP. The least-EP diet meant that AP was 7\% lower; however, NRRU increased by $8 \%$ with no significant change in GWP. The least-EI diet in the West reduced AP (17\%), but did increase NRRU by $17 \%$, with no significant difference in EP or GWP compared with the least-cost diet.

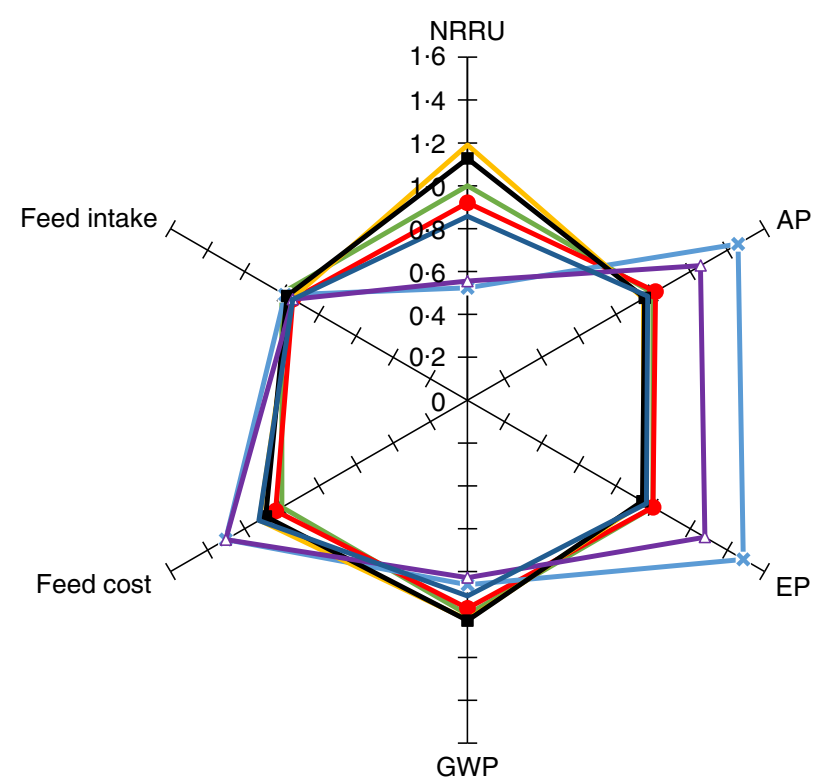

Fig. 3. The environmental impacts, feed cost and feed intake per kg of carcass weight for grower/finisher diets in Eastern Canada formulated for different objectives, represented as a fraction of the results for the least-cost diet. Least cost ( $\longrightarrow$ ), least feed cost per kg live weight gain; least-cost EFF ( - ), least cost/kg live weight gain while maximising feed efficiency within commercial constraints; NRRU (- - ), non-renewable resource use; AP ( $)$, acidification potential; EP (GWP ( $\triangle$ ), global warming potential; least EI ( $\leftrightharpoons$ ), least combined environmental impact score.

Table 5. The environmental impacts per kg of carcass weight for grower/finisher diets in Eastern Canada formulated for different objectives

\begin{tabular}{|c|c|c|c|c|c|c|c|c|}
\hline Impact category & Unit & Least cost & Least-cost EFF & Least NRRU & Least AP & Least EP & Least GWP & Least El \\
\hline NRRU & g Sb eq & 0.0063 & 0.00 & 0.0033 & 0.0075 & 0.0071 & 0.0035 & 0.0054 \\
\hline AP & $\mathrm{kg} \mathrm{SO}_{2}$ eq & 0.0548 & $0.0555^{\mathrm{NS}}$ & 0.0799 & 0.0520 & 0.0523 & 0.0688 & 0.0532 \\
\hline EP & $\mathrm{kg} \mathrm{PO}_{4}$ eq & 0.0140 & $0.0140^{\text {NS }}$ & 0.0208 & 0.0133 & 0.0132 & 0.0179 & 0.0135 \\
\hline GWP & $\mathrm{kg} \mathrm{CO} \mathrm{CO}_{2}$ eq & 2.09 & 2.03 & 1.80 & $2 \cdot 14^{\mathrm{NS}}$ & $2 \cdot 15$ & 1.73 & 1.91 \\
\hline CML environmental impact score & No units & $3 \cdot 67 \mathrm{E}-13$ & $3.65 \mathrm{E}-13$ & $4 \cdot 70 \mathrm{E}-13$ & $3.62 \mathrm{E}-13$ & $3 \cdot 60 \mathrm{E}-13$ & $4 \cdot 13 \mathrm{E}-13$ & $3.49 \mathrm{E}-13$ \\
\hline
\end{tabular}

eq, Equivalent; least cost, least feed cost per kg live weight gain; least-cost EFF, least cost/kg live weight gain while maximising feed efficiency within commercial constraints; NRRU, non-renewable resource use; AP, acidification potential; EP, eutrophication potential; GWP, global warming potential; least El, least combined environmental impact score; $\mathrm{CML}$, Institute of Environmental Sciences at Leiden University; NS, not significantly different from the least-cost diet $(P>0.05)$. 
Formulating sustainable diets for livestock

Table 6. The environmental impacts per $\mathrm{kg}$ of carcass weight for grower/finisher diets in Western Canada formulated for different objectives

\begin{tabular}{|c|c|c|c|c|c|c|c|c|}
\hline Impact category & Unit & Least cost & Least-cost EFF & Least NRRU & Least AP & Least EP & Least GWP & Least El \\
\hline IRRU & $\mathrm{kg}$ & 0.00797 & 0.00848 & 0.00427 & 0.0102 & 0.0086 & 0.0050 & 0.0093 \\
\hline AP & $\mathrm{kg} \mathrm{SO}_{2} \mathrm{eq}$ & 0.0648 & 0.0624 & 0.0827 & 0.0535 & 0.0604 & 0.0703 & 0.0540 \\
\hline $\mathrm{EP}$ & $\mathrm{kg} \mathrm{PO}_{4}$ eq & 0.0167 & $0.0160^{N S}$ & 0.0214 & $0.0162^{\mathrm{NS}}$ & 0.0150 & 0.0193 & $0.0160^{N S}$ \\
\hline GWP & $\mathrm{kg} \mathrm{CO} 2$ eq & $2 \cdot 31$ & $2 \cdot 33^{N S}$ & 1.87 & $2 \cdot 30^{\mathrm{NS}}$ & 2.23 & 1.75 & $2 \cdot 21^{\mathrm{NS}}$ \\
\hline CML environmental impact score & No units & $4 \cdot 34 \mathrm{E}-13$ & $4 \cdot 22 \mathrm{E}-13$ & $4.91 \mathrm{E}-13$ & $4.09 \mathrm{E}-13$ & $4 \cdot 10 \mathrm{E}-13$ & $4 \cdot 38 \mathrm{E}-13$ & $4.02 \mathrm{E}-13$ \\
\hline
\end{tabular}

eq, Equivalent; least cost, least feed cost per kg live weight gain; least-cost EFF, least cost/kg live weight gain while maximising feed efficiency within commercial constraints; NRRU, non-renewable resource use; AP, acidification potential; EP, eutrophication potential; GWP, global warming potential; least El, least combined environmental impact score; CML, Institute of Environmental Sciences at Leiden University; NS, not significantly different from the least-cost diet $(P>0.05)$.

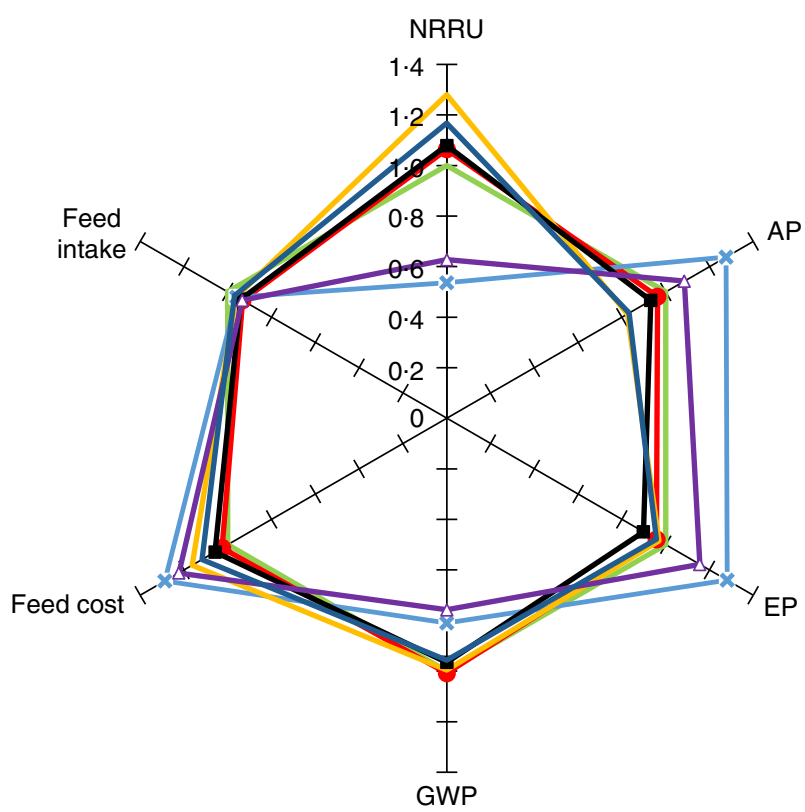

Fig. 4. The environmental impacts, feed cost and feed intake per $\mathrm{kg}$ of carcass weight for grower/finisher diets in Western Canada formulated for different objectives, represented as a fraction of the results for the least-cost diet. Least cost ( $\left({ }^{\prime}\right)$, least feed cost per kg live weight gain; least-cost EFF (C), least cost $/ \mathrm{kg}$ live weight gain while maximising feed efficiency within commercial constraints; NRRU $(-\mathcal{N}-)$, non-renewable resource use; AP ( $)$, acidification potential; EP (-), eutrophication potential; GWP ( $\triangle$ ), global warming potential; least EI ( $\longrightarrow$ ), least combined environmental impact score.

\section{Discussion}

As feed production and manure management are the main sources of environmental impact in pig production systems $^{(5,6,13,16)}$, it is logical to consider diet formulation as a mechanism to reduce the environmental impact of pig production. In this study, we formulated diets for the $G / F$ production stage as this is where the majority of feed intake occurs per finished $\mathrm{pig}^{(5)}$. There is also potential to formulate sow diets for environmental impact objectives to make reductions to the environmental impact of pig production systems. Although previous analysis of the farming systems modelled here showed that the proportion of environmental impacts from this production phase is approximately $15 \% / \mathrm{kg} \mathrm{ECW} \mathrm{for} \mathrm{most}$ impact categories ${ }^{(5)}$. Previous LCA studies have used scenario testing to demonstrate the potential for dietary changes to reduce the environmental impact of non-ruminant livestock systems $^{(12,21,56-58)}$. In this study, we used a different approach by developing a novel methodology, which integrated a cradle to farm gate LCA model into a diet formulation tool to formulate diets for specific environmental impact objectives. Methodologies such as this one allow nutritionists to integrate environmental impact objectives into diet formulations and for livestock producers to quantify the environmental impact of different feeding strategies. The methodology was associated with several challenges that are discussed below. The effectiveness of the methodology as a tool to reduce the environmental impacts of pig production systems and the strategies it identified to achieve this are then addressed.

\section{Methodological challenges}

Accounting for environmental impacts caused by ingredient choice, as well as nutrient excretion. Previous LCA studies using LCI data to formulate diets that minimise the environmental impacts per $\mathrm{kg}$ of $\operatorname{diet}^{(59,60)}$ have not taken into account the implications for nutrient excretion and the resulting environmental impacts. Predicting nutrient excretion is a common step in diet formulation. There are equations that can be integrated within animal growth models to predict nutrient excretion for a larger range of scenarios, using a more mechanistic approach than the one adopted in this study ${ }^{(1,61)}$. Previous studies have formulated diets where minimising nutrient excretion or levels of methane emissions were explicit objectives, as a way of incorporating environmental goals into least-cost formulation ${ }^{(62,63)}$. These studies, however, did not adopt a holistic LCA approach to quantify whether reductions in these specific emissions reduced the cradle to farm gate environmental impacts of the production system. The method developed in this study accounted for the aggregated environmental impacts during manure management caused by N, P and $\mathrm{K}$ excretion when formulating diets for environmental impact objectives. It predicted the feed intake required for pigs to reach a target weight with any $\mathrm{N}, \mathrm{P}$ and $\mathrm{K}$ not retained by the animal excreted via urine or faeces. A component of an LCA of pig farming systems was integrated into the diet formulation algorithm to predict the NRRU, AP, EP and GWP, which resulted from the storage and application to land of excreted nutrients as manure ${ }^{(23)}$. This included an estimate of the potential of the nutrients contained in the manure produced to replace mineral fertilisers being applied to fields in crop systems, an approach known as system expansion ${ }^{(64)}$. This approach incorporates the 
potential benefits of replacing mineral fertilisers with manure as well as accounting for the extra emissions this may cause. To our knowledge, this is the first time a diet formulation tool using a holistic LCA approach from cradle to farm gate has been developed to formulate livestock diets for environmental impact objectives.

Formulating diets for multiple environmental impact objectives. When formulating diets for environmental impact objectives in livestock systems, adopting a single metric is necessary in order to optimise diets for this purpose using linear programming. However, diets formulated to minimise one impact category may cause large increases in another type of environmental impact. If multiple environmental impact categories are to be accounted for when using linear programming, a combined environmental impact score must be defined. Combining environmental impacts in a meaningful way is a significant methodological challenge to LCA practitioners; its subjective nature means there is little agreement on how best to approach $\mathrm{it}^{(65)}$. In this study, the CML global normalisation methodology was adopted; there are many more complex methods for combining impacts that give various weightings to different types of impact ${ }^{(66,67)}$, but these methods are still based on subjective allocations of importance to the different impact categories. Such weightings are not currently recommended in the International Organization for Standardization standard for Life Cycle Impact Assessment ${ }^{(65,68)}$. It was not the purpose of this study to advance the discussion on how best to weigh environmental impacts. Any solution produced to minimise a metric for combined environmental impact is dependent on the methodology used to quantify it. Subjective choices such as which impact categories are included and how these categories are then weighted (to name only two) will hugely influence the outcome. The step of combining the impact categories provided the formulation tool with a framework to assess the trade-offs between decreases in one type of environmental impact and increases in another. Some methodologies have monetised the environmental impact categories using either the preferences of a panel, or the authors' stated preferences to give a monetary value to different impact categories ${ }^{(69,70)}$. Further work to define acceptable methodologies for the monetisation of environmental impacts would enhance efforts to reduce the environmental impact of livestock systems. This could allow feed cost and environmental impacts to be integrated into a single objective to formulate diets, which are economically and environmentally more sustainable.

\section{Allowing flexibility in the diet formulation rules to identify} the optimal nutritional strategies for environmental impact objectives. Previous studies that have formulated diets for environmental impact objectives have done so for a fixed minimum nutritional specification for energy $(\mathrm{MJ} / \mathrm{kg})$ and nutrient content $(\mathrm{g} / \mathrm{kg})$, above which feed intake was assumed not to be affected ${ }^{(59,60)}$. This is a fairly restrictive way to formulate diets, and there is no consideration of the trade-off between environmental impact per $\mathrm{kg}$ of feed and feed intake. In this study, the formulation algorithm accounted for the expected effect of energy density on feed intake and identified the optimum energy density across each feeding phase for a particular impact objective. This approach is common in commercial diet formulation as maximising gain to feed will not always result in the optimum outcome in terms of feed cost or other economic objectives ${ }^{(1)}$. This was evident in the diets formulated to minimise feed cost per kg LW gain, which were the least energy dense of all diets formulated in this study. Livestock diets have not been previously formulated for environmental impact objectives using this flexible approach to the nutritional density of the solution.

In this study, improving gain:feed ratio on a least-cost basis reduced the environmental impacts of the farming system, as shown by the least-cost EFF diet in both regions having a lower combined environmental impact score than the least-cost diets. The diets formulated for least NRRU, AP and EP, however, did not maximise gain:feed ratio in both the East and the West Canadian scenario. The optimum energy density of the G/F diet was also different for each of the impact objectives. Similarly the least-EI diets in the scenarios for Eastern and Western Canada also had differing energy densities, showing the need for flexibility when formulating diets for environmental impact objectives depending on the available ingredients. Formulating diets for a fixed minimum nutritional specification at an assumed feed intake would have restricted the ability of the tool to minimise both individual environmental impact categories and the combined environmental impact score of the system. This is the first study to present a diet formulation algorithm that has the flexibility to identify the optimal nutritional density of livestock diets for different environmental impact objectives. The study demonstrated how environmental impact objectives can be integrated into modern diet formulation tools. The integration of diet formulation and LCA could be utilised to weigh the relative costs of reducing specific types of environmental impact from modern pig farms through diet manipulation. The approach could also be used to help modern pig production systems adapt and limit their liability to environmental taxes imposed on them.

\section{Formulation strategies for environmental impact reduction}

In most cases (with the exception of EP in the east and AP in the west), diets formulated for environmental impact objectives had a lower total inclusion of whole cereals (maize, wheat or barley) than diets formulated for economic objectives. This is because when formulating diets for environmental impact objectives, the environmental 'cost' of production compared with the nutritional profile of these cereals is less favourable than their market value. When available, bakery meal was included at (or close to) maximum allowed levels in all diets formulated for environmental impact objectives. Bakery meal has relatively low levels of environmental impacts in the categories tested, and has high nutritional value as an ingredient in diets fed to growing pigs (although there are concerns about its variability) ${ }^{(50)}$. Apart from these two examples, there were a few uniform trends observed in the strategies adopted for different environmental impact objectives.

When minimising NRRU and GWP, high-protein diets were formulated with increased inclusions of soyameal and 
co-products such as wheat shorts, wheat bran and meat meal. Amino acid supplementation was not utilised when minimising NRRU and GWP. This contrasted with previous studies, conducted mainly in Europe, suggesting low-protein diets with amino acid supplementation as a method of reducing GWP in pig production systems ${ }^{(21,58,71)}$. The reason for the difference is that the majority of soyameal used in European animal feed is imported from South America ${ }^{(72)}$ and is associated with recent land use change, which carries a significant environmental impact penalty. Similarly, maize DDGS was also excluded from the least-GWP and least-NRRU diets because its production is associated with high levels of these impact categories (Table 1), due to energy inputs for drying and processing ${ }^{(22)}$. Previous LCA studies have also found that including maize DDGS in pig diets increased GWP in pig farming systems ${ }^{(16,23,73)}$

In order to minimise AP and $\mathrm{EP}$, diets were formulated with increased amino acid supplementation to minimise crude protein content. Other studies that have used scenario testing to assess the effect of amino acid supplementation in pig diets on the system's environmental impacts have made similar conclusions $^{(21,58)}$. The results from both regions showed that increased inclusions of maize DDGS can be used as part of balanced G/F diets to minimise EP and AP in pig farming systems. This finding contradicts previous studies that individually tested the effect of including DDGS in Canadian pig diets ${ }^{(23)}$. The reason for the contradiction is due to differences in formulation objectives, with previous studies formulating for least cost rather than formulating for environmental impact objectives. This highlights the advantage of explicitly formulating pig diets for environmental impact objectives. A diet formulation algorithm can be used to formulate a balanced solution that includes ingredients that reduce the overall levels of a particular impact category, while simultaneously accounting for the trade-off between changes in feed intake and potential reductions in the environmental impacts per $\mathrm{kg}$ of the diet fed.

\section{Effectiveness of optimisation as a strategy to reduce environmental impact in pig systems}

The results of this study showed that through optimising G/F diets specifically for the purpose of reducing the environmental impact of pig production, it is possible to reduce the overall levels of NRRU, AP, EP and GWP in both maize- and wheat/ barley-based diets. Relatively large proportional reductions were shown to be possible in the levels of NRRU and GWP in both regions when optimising to minimise the impacts individually. However, because of increases in EP and AP, these diets increased the combined environmental impact score of the system. Such outcomes can only be considered a reduction in the environmental impact of the system if environmental impact categories other than the objective (e.g. GWP) are considered unimportant. This is difficult to justify in the case of pig farming systems that have been shown to cause relatively small levels of GWP compared with meat produced from ruminants ${ }^{(9-11)}$. The results show the importance of considering multiple impact categories when using linear programming to optimise diets to reduce the environmental impacts of livestock systems.
Optimising $\mathrm{G} / \mathrm{F}$ diets to minimise the combined environmental impact score resulted in relatively modest reductions (approximately 5\%) in the pig farming system in both regions. Cost was not the limiting factor for further reduction of the combined environmental impact score of the system; as the least-EI diets in both regions were below the $30 \%$ increase limit on feed cost. Further reductions in the combined environmental impact score through diet optimisation were restricted by the contrasting formulation strategies required to minimise NRRU and GWP compared with those for AP and EP. The solutions for least NRRU and least GWP were high-protein diets, which included large amounts of low-value co-products. However, the diets for least EP and AP minimised dietary protein content and increased levels of amino acid and mineral supplementation; production of these ingredients had high NRRU and GWP. This meant the possible reductions in the combined environmental impact score were much lower than those for individual environmental impact categories such as GWP or NRRU.

There are examples of policies using financial penalties or rewards to provide economic incentives for livestock producers to reduce their environmental impacts. These have included taxes on spreading fertilisers in the European Union ${ }^{(74)}$ and payments to farmers for reducing the greenhouse gas emissions caused by farming activities in Australia (the carbon farming initiative $)^{(75)}$. Methodologies such as those presented here could be used to evaluate how livestock producers might adapt formulation strategies under such mechanisms, and whether these changes would reduce the cradle to farm gate environmental impact of livestock systems for a particular impact category. It is also possible to carry out sensitivity analyses in order to estimate the necessary levels of penalty or payments to incentivise changes that reduce the levels from cradle to farm gate by $x \%$ for a given impact category.

\section{Conclusions}

A modified diet formulation algorithm was designed, which integrated important elements of an existing LCA model into a linear programme for diet formulation, in order to formulate G/F diets for environmental impact objectives. The flexibility of this approach allowed it to identify the optimum nutritional composition of the diets for a particular environmental impact objective as well as altering the ingredient composition. The optimum energy density of the G/F diet was different for each of the environmental impact objectives. Through optimising diets for individual environmental impact categories, relatively large reductions in NRRU and GWP were found to be possible compared with the least-feed cost diet; however, these came at the expense of increases in AP and EP. The results showed that the easy solution to minimise environmental impacts is not always to feed a low-energy diet, high in co-products. This was demonstrated by the least-GWP diets, which in both regions were the most energy dense along with the least-cost EFF diets. Diets were also formulated to minimise a combined environmental impact score for NRRU, AP, EP and GWP, which enabled reductions in the environmental impacts of the system without any large increases in individual impact categories. Further studies to define acceptable methodologies to combine 
and monetise different categories of environmental impact could allow feed cost and environmental impacts to be integrated into a single objective. This would allow nutritionists to formulate diets that are economically and environmentally more sustainable. This study demonstrated how environmental impact objectives can be integrated into modern diet formulation tools for livestock production systems using LCA.

\section{Acknowledgements}

The authors would like to thank Peter Latham and Sugarich Ltd for providing usable data on the production process for bakery meal.

This project was sponsored by Trouw Nutrition Canada in the form of a postgraduate studentship to S. G. M.

This paper derives from the doctoral thesis of S. G. M. under the supervision of I. K., I. L. and N. F. All authors contributed to designing the formulation tool and the scenarios to be tested. S. G. M. constructed the diet formulation tool, formulated the diets and conducted the LCA model simulations. All the authors contributed to the interpretation of the outcomes and the reporting of the paper.

The authors declare that there are no conflicts of interest.

\section{Supplementary material}

For supplementary material/s referred to in this article, please visit http://dx.doi.org/doi:10.1017/S0007114516000763

\section{References}

1. Ferguson N (2014) Commercial application of integrated models to improve performance and profitability in pigs and poultry. In Nutritional Modelling in Pigs and Poultry, pp. 141-156 [N Sakmoura, R Gous, I Kyriazakis, et al., editors]. Wallingford, Oxfordshire: CABI.

2. Saddoris-Clemons K, Schneider J, Feoli C, et al. (2011) Costeffective feeding strategies for grow-finish pigs. Adv Pork Prod 22, 187-194.

3. Steinfeld H, Gerber P, Wassenaar T, et al. (2006) Livestocks Long Shadow-Environmental Issues and Options. Rome: FAO.

4. Macleod M, Gerber P, Opio C, et al. (2013) Greenhouse Gas Emissions from Pig and Chicken Supply Chains. Rome: FAO.

5. Mackenzie SG, Leinonen I, Ferguson N, et al. (2015) Accounting for uncertainty in the quantification of the environmental impacts of Canadian pig farming systems. J Anim Sci 93, 3130-3143.

6. Basset-Mens C \& Van Der Werf HMG (2005) Scenario-based environmental assessment of farming systems: the case of pig production in France. Agric Ecosyst Environ 105, 127-144.

7. Guinée JB, Gorrée M, Heijungs R, et al., (editors) (2002) Handbook on Life Cycle Assessment: An Operational Guide to the ISO Standards. Dordrecht: Kluwer Academic Publishers.

8. Weidmann T \& Minx J (2008) A definition of 'carbon footprint'. In Ecological Economics Research Trends, pp. 1-11 [CC Perstova, editor]. Hauppauge, NY: Nova Science Publishers.

9. de Vries M \& de Boer IJM (2010) Comparing environmental impacts for livestock products: a review of life cycle assessments. Livest Sci 128, 1-11.

10. Williams AG, Audsley E \& Sandars DL (2006) Determining the Environmental Burdens and Resource Use in the Production of Agricultural and Horticultural Commodities. Defra Research Project ISO205. Bedford: Cranfield University and Defra.
11. Eshel G, Shepon A, Makov T, et al. (2014) Land, irrigation water, greenhouse gas and reactive nitrogen burdens of meat, eggs, and dairy production in the United States. PNAS 111, 11996-12001.

12. Eriksson IE, Elmquist H, Stern S, et al. (2005) LCA case studies environmental systems analysis of pig production the impact of feed choice. Int J Life Cycle Assess Environ Anal Syst 10, 143-154.

13. Reckmann K, Traulsen I \& Krieter J (2013) Life Cycle Assessment of pork production: a data inventory for the case of Germany. Livest Sci 157, 586-596.

14. Dourmad JY, Ryschawy J, Trousson T, et al. (2014) Evaluating environmental impacts of contrasting pig farming systems with life cycle assessment. Animal 8, 2027-2037.

15. PorkCheckoff (2009) Quick facts: the pork industry at a glance. http://www.extension.umn.edu/youth/mn4-H/events/projectbowl/docs/pb-gl-Quick-Facts-The-Pork-Industry-at-a-Glance. pdf (accessed March 2013).

16. Thoma G, Nutter D, Ulrich R, et al. (2011) National Life Cycle Carbon Footprint Study for Production of US Swine. Des Moines, IA: National Pork Board.

17. Patience JF, Thacker PA \& de Lange CFM (editors) (1995) Diet formulation. In Swine Nutrition Guide, 2nd ed., pp. 119-132. Saskatoon, Saskatchewan, Canada: Prairie Swine Centre.

18. Van Der Werf HMG, Petit J \& Sanders J (2005) The environmental impacts of the production of concentrated feed: the case of pig feed in Bretagne. Agric Syst 83, 153-177.

19. Food and Agriculture Organization (2014) Environmental performance of animal feeds supply chains. Livestock Environmental Assessment and Performance Partnership. FAO, Rome. http://www.fao.org/3/a-mj751e.pdf (accessed October 2015).

20. Pelletier N, Arsenault N \& Tyedmers P (2008) Scenario modelling potential eco-efficiency gains from a transition to organic agriculture: life cycle perspectives on Canadian canola, corn, soy, and wheat production. Environ Manage 42, 989-1001.

21. Garcia-Launay F, van der Werf HMG, Nguyen TTH, et al. (2014) Evaluation of the environmental implications of the incorporation of feed-use amino acids in pig production using Life Cycle Assessment. Livest Sci 161, 158-175.

22. Swiss Centre for Life Cycle Inventories (2007) Ecoinvent Data 2.2 Final Reports No. 1-25. Dubendorf: Swiss Centre for Life Cycle Inventories.

23. Mackenzie SG, Leinonen I, Ferguson N, et al. (2016) Can the environmental impact of pig systems be reduced by utilising co-products as feed. J Clean Prod 115, 172-181.

24. Nielsen P, Nielsen A, Weidema B, et al.2003) LCA food database. www.lcafood.dk (accessed April 2014).

25. Ramirez AD, Humphries AC, Woodgate SL, et al. (2012) Greenhouse gas life cycle assessment of products arising from the rendering of mammalian animal byproducts in the UK. Environ Sci Technol 46, 447-453.

26. Blasi D, Kuhl GL, Drouillard JS, et al. (1998) Wheat middlings-composition, feed value and storage guidelines. Kansas State University. http://www.ksre.ksu.edu/bookstore/ pubs/MF2353.pdf (accessed February 2015).

27. Food and Agriculture Organization (2009) Agribusiness Handbook Wheat Flour. Agribusiness. Rome: FAO. https://www. responsibleagroinvestment.org/sites/responsibleagroinvestment. org/files/FAO_Agbiz handbook_Wheat Flour.pdf (accessed March 2013).

28. IPCC (2006) 2006 IPCC Guidelines for National Green House Gas Inventories. Volume 4: Agriculture, Forestry and Other Land Use. http://www.ipcc-nggip.iges.or.jp/public/2006gl/ index.html (accessed December 2013).

29. Sheppard SC, Bittman S, Swift ML, et al. (2010) Farm practices survey and modelling to estimate monthly $\mathrm{NH}_{3}$ emissions 
from swine production in 12 Ecoregions of Canada. Can J Anim Sci 90, 145-158.

30. Weatherbase (2014) Canada-weather averages. http:// www.weatherbase.com/weather/state.php3?c=CA (accessed May 2014).

31. Beaulieu M (2004) Manure Management in Canada. Ottawa, Ontario: Statistics Canada. http://publications.gc.ca/ Collection/Statcan/21-021-M/21-021-MIE2004001.pdf (accessed February 2014).

32. Statistics-Canada (2003) Manure storage in Canada. http:// www.statcan.ca/english/freepub/21-021-MIE/free.htm (accessed March 2013)

33. Nguyen TLT, Hermansen JE \& Mogensen L (2011) Environmental Assessment of Danish Pork. Aarhaus: Aarhus University. http://web.agrsci.dk/djfpublikation/djfpdf/ir_103_54761_ indhold_internet.pdf (accessed June 2013).

34. Korol M (2004) Fertilizer and pesticide management in Canada. Ottawa, Ontario: Statistics Canada. 1-41. http://www.statcan.ca/english/freepub/21-021- MIE/free.htm (accessed June 2013).

35. Lammers PJ, Honeyman MS, Harmon JD, et al. (2010) Energy and carbon inventory of Iowa swine production facilities. Agric Syst 103, 551-561.

36. US Climate Data (2014) Climate-Mason City, Iowa. http:// www.usclimatedata.com/climate/mason-city/iowa/united-states/ usia0541 (accessed May 2014)

37. Statistics-Canada (2013) Table 127-0002-electric power generation, by class of electricity producer, annual (megawatt hour). http://www5.statcan.gc.ca/cansim/a26?lang=eng\&retrLang= eng\&id $=1270003 \& \mathrm{paSer}=\&$ pattern $=\& \mathrm{stByVal}=1 \& \mathrm{p} 1=1 \& \mathrm{p} 2=-1$ $\&$ tabMode $=$ dataTable\&csid $=($ accessed April 2014).

38. British Standards Institution (2011) PAS 2050: 2011 Specification for the Assessment of the Life Cycle Greenhouse Gas Emissions of Goods and Services. London: British Standards Institution.

39. Institute of Environmental Sciences at Leiden University (CML) (2002) CML-IA characterisation factors. http://cml.leiden.edu/ software/data-cmlia.html (accessed November 2012).

40. Huijbregts MAJ, Breedveld L, Huppes G, et al. (2003) Normalisation figures for environmental life-cycle assessment: The Netherlands (1997/1998), Western Europe (1995) and the world (1990 and 1995). J Clean Prod 11, 737-748.

41. Mason A (2011) OpenSolver - an open source add-in to solve linear and integer progammes in Excel. In Operations Research Proceedings, pp. 401-406 [D Klatte, H-J Lüthi and K Schmedders, editors]. Berlin: Springer.

42. Stein Monogastric Nutrition Laboratory (2014) Feed ingredient database. http://nutrition.ansci.illinois.edu/feed_database. html (accessed July 2014).

43. National Research Council (2012) Feed ingredient composition. In Nutrient Requirements of Swine, 11th ed. pp. 239-367. Washington, DC: The National Academies Press.

44. Hazzeldine MJ (2010) Premier Atlas 2010: Ingredient Matrix [I Mackinson, editor]. Rugeley, UK: Premier Nutrition Products Ltd.

45. National Research Council (2012) Nutrient requirement tables. In Nutrient Requirements of Swine, 11th ed. pp. 208-239. Washington, DC: The National Academies Press.

46. Kyriazakis I \& Emmans GC (1995) The voluntary feed intake of pigs given feeds based on wheat bran, dried citrus pulp and grass meal in relation to measurements of feed bulk. Br J Nutr 73, 191-207.

47. Patience JF (2012) The influence of dietary energy on feed efficiency in grow-finish swine. In Feed Efficiency in Swine, pp. 101-130 [JF Patience, editor]. Wageningen: Wagengen Academic Publishers.
48. Statistics-Canada (2014) Feed grain facts. http://www.agr.gc.ca/ eng/industry-markets-and-trade/statistics-and-market-information/ by-product-sector/crops/crops-market-information-canadianindustry/feed-grain-facts/?id=1378744006272\#alt （accessed February 2015).

49. Brisson Y (2014) The changing face of the Canadian hog industry. http://www.statcan.gc.ca/pub/96-325-x/2014001/ article/14027-eng.pdf (accessed December 2014)

50. Ontario Ministry of Agriculture, Food and Rural Affairs (2012) Comparative feed values for swine. http://www.omafra.gov. on.ca/english/livestock/swine/facts/03-003.htm\#composition (accessed August 2014)

51. Wellock IJ, Emmans GC \& Kyriazakis I (2003) Modelling the effects of thermal environment and dietary composition on pig performance: model logic and concepts. Anim Sci $\mathbf{7 7}$, $255-266$.

52. Symeou V, Leinonen I \& Kyriazakis I (2014) Modelling phosphorus intake, digestion, retention and excretion in growing and finishing pigs: model description. Animal 8, $1612-1621$

53. Rigolot C, Espagnol S, Pomar C, et al. (2010) Modelling of manure production by pigs and $\mathrm{NH}_{3}, \mathrm{~N}_{2} \mathrm{O}$ and $\mathrm{CH}_{4}$ emissions. Part I: animal excretion and enteric $\mathrm{CH}_{4}$, effect of feeding and performance. Animal 4, 1401-1412.

54. Lloyd SM \& Ries R (2007) Characterizing, propagating and and analyzing uncertainty in Life-Cycle Assessment - a survey of quantitative approaches. J Ind Ecol 11, 161-179.

55. Leinonen I, Williams AG, Wiseman J, et al. (2012) Predicting the environmental impacts of chicken systems in the United Kingdom through a life cycle assessment: broiler production systems. Poult Sci 91, 8-25.

56. Leinonen I, Williams AG, Waller AH, et al. (2013) Comparing the environmental impacts of alternative protein crops in poultry diets: the consequences of uncertainty. Agric Syst 121, $33-42$.

57. Meul M, Ginneberge C, Van Middelaar CE, et al. (2012) Carbon footprint of five pig diets using three land use change accounting methods. Livest Sci 149, 215-223.

58. Ogino A, Osada T, Takada R, et al. (2013) Life cycle assessment of Japanese pig farming using low-protein diet supplemented with amino acids. Soil Sci Plant Nutr 59, 107-118.

59. Nguyen TTH, Bouvarel I, Ponchant P, et al. (2012) Using environmental constraints to formulate low-impact poultry feeds. J Clean Prod 28, 215-224.

60. Moe A, Koehler-munro K, Bryan R, et al. (2014) Multi-criteria decision analysis of feed formulation for laying hens. In Proceedings of 9th International Conference on LCA in the Agri-food Sector, pp. 647-653 [R Schenck and D Huizenga, editors]. San Francisco, CA: American Center for Life Cycle Assessment.

61. van Milgen J, Valancogne A, Dubois S, et al. (2008) InraPorc: a model and decision support tool for the nutrition of growing pigs. Anim Feed Sci Technol 143, 387-405.

62. Pomar C, Dubeau F, Létourneau-Montminy M-P, et al. (2007) Reducing phosphorus concentration in pig diets by adding an environmental objective to the traditional feed formulation algorithm. Livest Sci 111, 16-27.

63. Moraes LE \& Fadel JG (2013) Minimising environmental impacts of livestock production using diet optimization models. In Sustainable Animal Agriculture, pp. 67-82 [E Kebreab, editor]. Wallingford, Oxfordshire: CABI Publishing

64. Thomassen MA, Dalgaard R, Heijungs R, et al. (2008) Attributional and consequential LCA of milk production. Int J Life Cycle Assess 13, 339-349. 
65. Finnveden G, Hauschild MZ, Ekvall T, et al. (2009) Recent developments in Life Cycle Assessment. J Environ Manage 91, $1-21$.

66. Goedkoop M \& Spriensma R (2001) The Eco-indicator 99 - a damage oriented method for Life Cycle Impact Assessment. http://www.pre-sustainability.com/download/EI99_annexe_v3. pdf (accessed March 2013).

67. Soares SR, Toffoletto L \& Deschênes L (2006) Development of weighting factors in the context of LCIA. I Clean Prod 14, 649-660

68. International Organisation for Standardisation (2006) EN ISO 14044. Brussels: European Commission for Standardisation.

69. Weidema BP (2009) Using the budget constraint to monetarise impact assessment results. Ecol Econ 68, 1591-1598.

70. Finnveden G, Eldh P \& Johansson J (2006) Weighting in LCA based on ecotaxes-development of a mid-point method and experiences from case studies. Int J Life Cycle Assess 11, 81-88.

71. Mosnier E, van der Werf HMG, Boissy J, et al. (2011) Evaluation of the environmental implications of the incorporation of feed-use amino acids in the manufacturing of pig and broiler feeds using Life Cycle Assessment. Animal 5 , 1972-1983.

72. Krautgartner R, Henard M, Rehder LE, et al. (2013) Oilseeds and Products Annual: Ample Soybean World Supplies to Boost EU-27 Soybean Meal Consumption. Global Agricultural Information Network Report. USDA Foreign Agricultural Service. http://gain. fas.usda.gov/Recent GAIN Publications/Oilseeds and Products Annual_Vienna_EU-27_4-5-2013.pdf (accessed August 2015).

73. Stone JJ, Dollarhide CR, Benning JL, et al. (2012) The life cycle impacts of feed for modern grow-finish Northern Great Plains US swine production. Agric Syst 106, 1-10.

74. ECOTEC Research and Consulting (2001) Taxes on fertilisers and mineral surpluses. In Study on the Economic and Environmental Implications of the Use of Environmental Taxes and Charges in the European Union, pp. 129-151. Brussels: ECOTEC Research and Consulting. http://ec.europa.eu/environment/ enveco/taxation/pdf/ch9_fertilisers.pdf (accessed August 2015).

75. Department of Environment - Australian Government (2012) About the carbon farming initiative. http://www.environment. gov.au/climate-change/emissions-reduction-fund/cfi/about (accessed August 2015). 